\title{
Ratings-Based Regulation and Systematic Risk Incentives
}

\author{
by \\ Giuliano Iannotta \\ Department of Economics and Business Administration \\ Universitá Cattolica \\ Email: giuliano.iannotta@unicatt.it \\ George Pennacchi \\ Department of Finance \\ University of Illinois \\ Email: gpennacc@illinois.edu \\ João A.C. Santos \\ Federal Reserve Bank of New York \& Nova School of Business and Economics \\ Email: joao.santos@ny.frb.org
}

First Draft: August 2011

This Draft: April 2018

\begin{abstract}
Our model shows that when regulation is based on credit ratings, banks with low charter value maximize shareholder value by minimizing capital and selecting identically-rated loans and bonds with the highest systematic risk. This regulatory arbitrage is possible if the credit spreads on same-rated loans and bonds are greater when their systematic risk (debt beta) is higher. We empirically confirm this relationship between credit spreads, ratings, and debt betas. We also show that banks with lower capital select syndicated loans with higher debt betas and credit spreads, and banks with lower charter value choose overall assets with higher systematic risk.

An earlier version of this paper was titled "Bank Regulation, Credit Ratings, and Systematic Risk." Valuable comments were provided by three anonymous referees, the editor Itay Goldstein, Tobias Berg, Thomas Cooley, Timotej Homar, Christine Parlour, Andrea Resti, Francesco Saita, Andrea Sironi, René Stulz, Andrew Winton and participants of the 2011 International Risk Management Conference, the 2011 Bank of Finland Future of Risk Management Conference, the 2012 Financial Risks International Forum, the 2012 Red Rock Conference, the 2012 FDIC Bank Research Conference, the 2012 Banque centrale du Luxembourg Conference, the 2013 Financial Intermediation Research Society Meetings, the 2013 Banco de Portugal Conference, the 2014 Wharton Liquidity and Financial Crises Conference, and seminars at Copenhagen Business School, the Federal Reserve Banks of Cleveland and San Francisco, the Federal Reserve Board, HEC Paris, Imperial College, Indiana University, INSEAD, the Korea Deposit Insurance Corporation, Universitá Bocconi, Universitat Pompeu Fabra, the University of Tennessee, the University of Virginia, and Warwick Business School. We are very grateful to CAREFIN for providing financial assistance. The views stated herein are those of the authors and are not necessarily those of the Federal Reserve Bank of New York or the Federal Reserve System.
\end{abstract}




\section{Introduction}

Governments insure the liabilities of several types of financial institutions. Prime examples are federal government insurance of bank deposits and state government guarantees of insurance company policies. ${ }^{1} \mathrm{~A}$ consequence of these guarantees is that financial institutions may take excessive risks that expose governments to large losses from insolvencies (e.g., Kareken and Wallace (1978)). While regulation, such as minimum capital standards, aims to reduce these risk-taking incentives, the current regulatory framework may actually worsen a particular type of moral hazard. Kupiec (2004) and Pennacchi (2006) show that when regulation fails to differentially penalize systematic and idiosyncratic risks, banks and insurance companies may have incentives to make loans and invest in bonds that are highly likely to suffer losses during an economic downturn. The danger is that financial institutions will herd into systematically-risky investments that increase the likelihood of systemic failures.

In this paper, we begin with a model that illustrates how moral hazard can result from ratings-based capital standards. These standards can lead to regulatory arbitrage whereby banks with low charter (franchise) value choose assets with high systematic risk and binding capital requirements. This arbitrage arises when capital standards are based on external or internal credit ratings that reflect "real-world" (physical) expected default losses and not “risk-neutral” (systematic risk-adjusted) expected default losses. We extend a standard structural model of an insured financial institution to show that low charter value creates a desire to minimize capital, which can be accomplished under ratings-based regulation by choosing systematically-risky bonds and loans.

Next we provide empirical evidence consistent with the model. This evidence comes in two parts. First, we show that there is, indeed, scope for such arbitrage because identically-rated bonds and loans display significant differences in yields (credit spreads) that reflect differences in their systematic default risks. Thus, by investing in a relatively systematically-risky bond or loan, a bank or insurance company earns a systematic risk premium but is not penalized by higher ratings-based capital requirements. The financial institution can exploit this guarantee subsidy and increase its shareholder value simply by selecting the highest yielding bonds and loans of a given regulatory credit rating, a form of "reaching for yield.”

\footnotetext{
${ }^{1}$ Another example is federal government insurance of private defined-benefit pension plans. Brown (2010) surveys various government insurance programs.
} 
Second, we investigate systematic risk-taking by banks. Examining commercial banks' investments in syndicated loans, we find that banks with relatively low capital ratios select loans of a given credit rating that have relatively high systematic risk and relatively high credit spreads. In addition, we derive model-based estimates of charter values and total asset portfolio systematic risks for a subsample of banks that have publicly-traded stock and credit default swaps (CDS). These estimates confirm our model's prediction that relatively low charter value leads banks to choose assets with overall higher systematic risk.

Our paper contributes to two strands of the literature. The first relates debt yields to systematic default risks. Hull, Predescu, and White (2005) show that average credit spreads of corporate bonds grouped by their credit ratings are much higher than historical loss rates for their rating class, suggesting the presence of a systematic risk premium. Elton, Gruber, Agrawal, and Mann (2001) find that average credit spread changes of corporate bond portfolios sorted by rating class and maturity are related to Fama and French (1993) risk factors. Driessen (2005) studies the components of corporate yields and, like the previous papers, restricts systematic risk to be the same for a given rating class. Systematic risk factors also explain individual corporate bonds' changes in spreads (Collin-Dufresne, Goldstein, and Martin (2001)) and excess returns (Schaefer and Strebulaev (2008)), though these findings may be due to changes in expected default losses or systematic risk premia. Perhaps closest to our paper is Hilscher and Wilson (2017) who relate a corporation’s long-term Standard \& Poor's (S\&P) rating to various time-series estimates of the firm’s default risk. They find that the firm's credit rating better reflects its systematic default risk than its simple probability of failure.

Our test of how debt yields reflect systematic risk is distinct from this previous literature and is motivated by a very specific question. We ask whether differences in the credit spreads of identically-rated corporate bonds and syndicated loans are higher when the debt has greater systematic default risk. An affirmative answer to this question is a necessary condition for the plausibility of our particular theory of ratings-based regulatory arbitrage. Indeed using data on either bonds or loans, we find that credit spreads of identically-rated debt are significantly greater when the debt’s issuer has a higher systematic risk of default. ${ }^{2}$ Our measure of systematic risk, referred to as “debt beta," is theoretically-grounded and calculated from corporate information available at the time that the bond or loan is originated. Moreover, since we use the

\footnotetext{
2 This result may be surprising given Hilscher and Wilson's (2017) finding that credit ratings better reflect systematic risk than the probability of default. However, they are not necessarily inconsistent since we show that credit ratings do not account for all of a corporation's systematic default risk reflected in its debt's credit spreads. Moreover, we use the credit rating and credit spread of the individual debt issue while they use the credit rating of the firm.
} 
debt's credit rating and its credit spread at the time of origination, our test avoids problems arising from “stale” credit ratings or from differences between the issuing firm's rating and its debt's (issue) rating.

Our test of whether credit spreads reflect systematic default risk beyond that implied by the security's rating has precedent but for non-corporate, “structured” securities. Coval, Jurek, and Stafford (2009) note that pooling loans diversifies away idiosyncratic risk, so that mortgage-backed securities (MBS), assetbacked securities (ABS), and collateralized debt obligations (CDOs) possess higher systematic risk compared to identically-rated corporate bonds. Yet, they fail to uncover evidence of a relatively higher systematic risk premium in structured security yields. However, other research, including Collin-Dufresne, Goldstein, and Yang (2012), finds otherwise. ${ }^{3}$

Having confirmed the potential for regulatory arbitrage by choosing the most systematically-risky and highest credit spread debt of a given credit rating, our paper's second main contribution tests for such behavior by U.S. commercial banks. Prior research has found evidence consistent with ratings-based arbitrage by other government-insured financial institutions. Becker and Ivashina (2015) study insurance companies' choice of corporate bonds. Among bonds with similar credit ratings, they document that insurance companies tend to select a greater proportion of bonds with relatively high credit spreads compared to the bonds chosen by uninsured financial institutions. ${ }^{4}$ This behavior is most prevalent for insurance companies with lower regulatory capital and leads to greater systematic risk exposure. Merrill, Nadauld, and Strahan (2014) provide complementary evidence that insurance companies suffering the greatest capital declines during the early 2000's shifted their portfolios to highly-rated, but more systematically-risky, structured securities. ${ }^{5}$ Efing (2015) analyzes German banks and finds that those with relatively low capital invest in ABS with relatively high credit spreads compared to ABS of the same rating.

Our paper is the first to investigate banks’ systematic risk-taking by studying their investment choices both at the loan level and at the aggregate asset level. First, we analyze 165 U.S. banks' investments in syndicated loans using data from the Shared National Credit Program and find that banks with lower capital

\footnotetext{
${ }^{3}$ Chernenko, Hanson, and Sunderam (2014) find that pre-crisis average yields on AAA-rated non-prime residential MBS and CDOs were higher by 18 bp and 30 bp, respectively, compared to the average yield on AAA-rated corporate bonds. Merrill, Nadauld, and Strahan (2014) also estimate that the average yields on AAA-rated structured securities were almost $36 \mathrm{bp}$ higher than the average yield on AAA-rated corporate bonds.

${ }^{4}$ As an example, they report that among newly issued bonds in the AAA to A regulatory rating class, insurance companies purchase $75 \%$ of bonds in the lowest spread quartile and $82 \%$ of bonds in the highest spread quartile, and this difference is statistically significant.

${ }^{5}$ Chernenko, Hanson, and Sunderam (2014) also show that holdings of high-yielding structured securities were greater for insurance companies that were poorly capitalized and that had a stock, rather than mutual, organization.
} 
ratios tend to invest in loans with the highest systematic risk (debt betas). Moreover, the loans chosen by these banks have relatively high credit spreads conditional on the loans' ratings. Thus, consistent with our theory of regulatory capital arbitrage, these lower-capitalized banks appear to reach for yield by choosing high credit spread, high debt beta loans.

Second, we investigate systematic risk-taking at the aggregate asset portfolio level using a sample of banks that have both publicly-traded stock and CDS contracts. Combining stock market and CDS data allows us to extract model-implied measures of a bank's charter value and the systematic risk of its aggregate asset portfolio. As predicted by our theory, we find an inverse relationship between these banks' charter values and the systematic risks of their asset portfolios.

Our paper is certainly not the only one to identify flaws in risk-based capital standards. For example, Acharya, Schnabl, and Suarez (2013) document that bank credit lines backing commercial paper conduits were de facto credit guarantees but qualified under Basel standards as liquidity guarantees. Thus, banks’ riskweight to the credit exposure was only $10 \%$ of that had the same exposure been recorded on-balance sheet. Acharya and Steffen (2015) find that low-capitalized European banks took advantage of zero Basel II riskweights to increase their holdings of the riskiest sovereign debt. Boyson, Falhenbrach, and Stulz (2016) show that low-charter value U.S. banks issued Trust Preferred Securities that effectively increased their leverage without lowering their Tier 1 regulatory capital ratio.

The shortcoming from basing capital requirements on credit ratings is more subtle than these other flaws of risk-based regulation. Yet its consequences are potentially devastating to financial system stability. The evidence we present does not simply imply that ratings measure bond and loan default risks with error, so that ratings-based regulation is imperfect. If, relative to credit spreads, ratings errors were purely idiosyncratic, there would be less concern with banks "reaching for yield” by choosing the highest creditspread debt of a given rating. Rather, we show that credit spreads reflect systematic risk not accounted for in ratings, and banks with low charter value and capital select loans and assets with not only higher credit spreads but also greater systematic risk. These findings are worrisome because they imply that ratings-based regulation leads low charter value banks to choose the least capital and the most systematically risky 
investments, thereby making simultaneous failures particularly sensitive to economic downturns. ${ }^{6}$ Besides worsening systemic risk, ratings-based regulation can give banks a preference for funding borrowers with high systematic risk, thereby misallocating the economy's capital toward excessively pro-cyclical projects.

The flaw in ratings-based regulation that leads banks to choose systematically-risky common exposures highlights a broader point. To avoid regulatory arbitrage, capital standards must not only penalize systematic risks but must also properly account for the correlation structure of a bank's portfolio. Regulation that imposes asset-specific capital charges without reference to the asset return correlations of a bank's total asset portfolio can create incentives for banks to take excessive portfolio risk, even if it is not systematic.

The paper proceeds as follows. Section 2 presents a model where ratings-based regulation gives low charter value banks incentives to minimize capital and take high systematic risks. Section 3 confirms the model's assumption that the credit spreads of identically-rated corporate bonds or syndicated loans are higher when issuers have more systematic default risk. Section 4 presents direct evidence of regulatory arbitrage by showing that U.S. banks with relatively low capital or charter value select syndicated loans and overall asset portfolios with relatively higher credit spreads and systematic risks. Section 5 concludes.

\section{A Model of Incentives under Ratings-Based Capital Requirements}

This section illustrates why ratings-based regulation can create incentives for low charter value financial institutions to take high systematic risk. Its model has similarities to the binomial models in Kupiec (2004) and Pennacchi (2006), but focuses on the specific effects of ratings-based regulation and uses the continuous-time setting of Merton $(1974,1977)$ and Galai and Masulis (1976). The model derives variables, including a "debt beta” measure of systematic risk, that are directly employed in the paper’s empirical tests.

\subsection{Model Assumptions}

A financial institution is assumed to invest in a portfolio of bonds and loans that it funds by issuing shareholders' equity and government-insured liabilities. For concreteness, we refer to this institution as a “bank” and its liabilities as “deposits.” However, Cummins (1988) shows that with minor modeling changes, the institution can be interpreted as an "insurance company” and its liabilities as "insurance policies.”

\footnotetext{
${ }^{6}$ Other models, such as Penati and Protopapadakis (1988) and Acharya and Yorulmazer (2007), predict that banks are motivated to make common investments, though not necessarily systematically risky ones. The common exposure incentive in these models arises because simultaneous bank failures make a government bailout more likely. Our paper predicts herding into systematically risky exposures even if doing so does not raise the likelihood of a bailout.
} 
At the initial date 0 , the bank issues insured deposits of $D_{0}$ on which it pays the interest rate $r_{d} \leq r$, where $r$ is the competitive, default-free interest rate. As in Merton (1978) and Marcus (1984), a belowcompetitive deposit interest rate is a source of "charter" or "franchise” value. Shareholders contribute equity capital equal to $K_{0}$, so initially the bank has tangible assets worth $A_{0}=D_{0}+K_{0}$. These assets are a portfolio of default-risky bonds and loans issued by firms in $m$ industries that are exposed to different sources of risk. Each firm has a capital structure that satisfies the assumptions in Merton (1974). If the bank maintains constant portfolio proportions invested in the $m$ industries, Appendix A shows that the rate of return on the bank's total assets is

$$
\begin{aligned}
\frac{d A_{t}}{A_{t}} & =\mu d t+\sum_{i=1}^{m} \sigma_{A, i} d z_{i} \\
& =\mu d t+\sigma d z
\end{aligned}
$$

where $\sigma_{A, i}$ is the volatility of returns from the bank's loans and bonds of firms in industry $i, d z_{i}$ is the

Brownian motion process specific to firm asset returns in industry $i, d z_{i} d z_{j}=\rho_{i j} d t, \sigma^{2}=\sum_{j}^{m} \sum_{i=1}^{m} \sigma_{A, j} \sigma_{A, i} \rho_{i j}$, and $d z \equiv \frac{1}{\sigma} \sum_{i=1}^{m} \sigma_{A, i} d z_{i}$. Assuming the Capital Asset Pricing Model (CAPM) holds, Appendix A shows that the expected rate of return on the bank's asset portfolio satisfies the relationship ${ }^{7}$

$$
\mu=r+\varphi_{M} \beta
$$

where $\varphi_{M}>0$ is the excess expected return on the market portfolio of all assets (or "equity premium"), $\beta \equiv \sum_{i=1}^{m} \omega_{i} \beta_{D, i}$ is the bank's total asset portfolio beta, $\omega_{i}$ is the bank's proportion of total assets held in bonds and loans of firms in industry $i$, and $\beta_{D, i}$ is the average debt beta of firms in industry $i .^{8}$

A government regulator sets the bank’s risk-based capital requirement and deposit insurance premium. The premium is set at date 0 but payable at the future date $T$, which also is the time that the regulator audits the bank. Let $p$ be the (continuously-compounded) annual premium rate per deposit, so that the bank's total premium to be paid at date $T$ is $D_{T}\left(e^{p T}-1\right)$ and the sum of deposits plus premium payable at date $T$ is

\footnotetext{
${ }^{7}$ As in Merton (1978 p. 440), it is assumed that the bank pays a less-than-competitive deposit rate because depositors face high costs of transacting in securities markets. Yet enough lower-cost investors trade in securities markets and make them "sufficiently perfect" so that the capital asset pricing model holds.

${ }^{8}$ For analytical simplicity the bank is assumed to rebalance its loan and bond exposures such that industry and total asset volatilities remain constant. A richer model, such as Gornall and Strebulaev (2017) or Nagel and Purnanandam (2017), would allow asset volatilities and debt betas to rise with declines in the market portfolio.
} 
$D_{T} e^{p T}=D_{0} e^{\left(r_{d}+p\right) T} .9$ Similar to Merton (1977), the bank fails and is closed at date $T$ by the regular if $A_{T}<$ $D_{T} e^{p T}$. The government regulator/deposit insurer incurs any loss required to pay off insured deposits.

\subsection{Capital Requirements: Fair versus Ratings-Based}

Research dating back to Merton (1977) recognizes that fair deposit insurance and capital standards equate the value of a bank's insurance premium to the present value of its insurance losses, which equals a put option written on the bank's assets with an exercise price equal to its promised payments:

$$
\begin{aligned}
\underbrace{e^{-r T} D_{T}\left(e^{p T}-1\right)}_{\text {Value of Premium }} & =\underbrace{e^{-r T} E^{Q}\left[\max \left(D_{T} e^{p T}-A_{T}, 0\right)\right]}_{\text {Value of Insurance Losses }} \\
& =e^{-r T} D_{T} e^{p T} N\left(-d_{2}\right)-\left(K_{0}+D_{0}\right) N\left(-d_{1}\right) \\
& \equiv \operatorname{Put}\left(K_{0}+D_{0}, D_{T} e^{p T}, T\right)
\end{aligned}
$$

where $\mathrm{E}^{Q}[\cdot]$ is the "risk-neutral" expectation, ${ }^{10} d_{1}=\left[\ln \left(\left(K_{0}+D_{0}\right) /\left(e^{-r T} D_{T} e^{p T}\right)\right)+\frac{1}{2} \sigma^{2} T\right] /(\sigma \sqrt{T})$, $d_{2}=d_{1}-\sigma \sqrt{T}$, and $\operatorname{Put}\left(A_{0}, X, T\right)$ is the value of a Black-Scholes put option written on assets currently worth $A_{0}$, having exercise price $X$, and time until maturity of $T$. Key to equation (3) is that initial capital, $K_{0}$, is set fairly when it makes the discounted risk-neutral expected losses, Put $\left(K_{0}+D_{0}, D_{T} e^{p T}, T\right)$, equal to the value of the government insurance premium.

As we explain in more detail in Section 4, in practice deposit insurance premiums are largely insensitive to risk and do not account for differences in systematic risk. Moreover, external credit ratings set by rating agencies such as Moody’s and S\&P or internal credit ratings from Value at Risk (VaR) calculations are primarily based on real-world or "physical” expected default losses. As our empirical work confirms, identically-rated debt can have sizable differences in systematic default risk and credit spreads. An implication is that ratings-based capital requirements can be fair for only a single level of systematic risk or debt beta, and the fair debt beta for a given rating's capital charge may differ from the actual beta of a bank's loan or bond having that rating. So, while equation (2) shows that a bank's true expected rate of return on assets equals $\mu=r+\varphi_{M} \beta$, actual capital requirements reflect an expected bank asset rate of return equal to

\footnotetext{
${ }^{9}$ This insurance premium is analogous to a credit spread on deposits if deposits were competitively-priced $\left(r_{d}=r\right)$ and uninsured. In the absence of deposit insurance and regulation, uninsured depositors would set the credit spread, $p$, to make the date 0 fair value of their default-risky deposits equal to $D_{0}$, the amount they contribute initially.

${ }^{10}$ The risk-neutral asset return process is $d A_{t} / A_{t}=r d t+\sigma d z^{Q}$.
} 
$\mu_{B}=r+\varphi_{M} B$ where $B \equiv \sum_{i=1}^{m} \omega_{i} B_{D, i}$ and $B_{D, i}$ is the average debt beta that ratings-based regulation assigns to the bank’s loans and bonds of industry $i$. Hence, $B$ is the bank's portfolio beta implied by ratings-based standards, and in general $B \neq \beta$ so that $\mu_{B} \neq \mu$.

Accounting for this disparity between true and capital regulation-implied betas of the bank's assets, the actual relationship between premiums and minimum regulatory capital, $K_{\min }$, satisfies:

$$
\begin{aligned}
e^{-r T} D_{T}\left(e^{p T}-1\right) & =\underbrace{e^{-r T} D_{T} e^{p T} N\left(-d_{2}^{B}\right)-\left(K_{\min }+D_{0}\right) e^{\varphi_{M}(\beta-B) T} N\left(-d_{1}^{B}\right)}_{\text {Calculated Value of Insurance Losses Using Ratings }} \\
& =\operatorname{Put}\left(\left(K_{\min }+D_{0}\right) e^{\varphi_{M}(\beta-B) T}, D_{T} e^{p T}, T\right)
\end{aligned}
$$

where $d_{1}^{B}=\left[\ln \left(\left(K_{\min }+D_{0}\right) e^{\varphi_{M}(\beta-B) T} /\left(e^{-r T} D_{T} e^{p T}\right)\right)+\frac{1}{2} \sigma^{2} T\right] /(\sigma \sqrt{T})$ and $d_{2}^{B}=d_{1}^{B}-\sigma \sqrt{T}$. The ratingsbased standards in (4) lead to the same Black-Scholes formula as (3) except that the underlying asset value $\left(K_{\min }+D_{0}\right)$ is replaced everywhere with $\left(K_{\min }+D_{0}\right) e^{\varphi_{M}(\beta-B) T}$. Since put options are decreasing functions of their underlying asset value, when $\beta>B$ the option value in equation (4) is less than that in equation (3). In turn, actual minimum capital standards, $K_{\min }$, are lower than the corresponding fair, no-subsidy level.

The intuition for this result is that by choosing a higher asset portfolio beta of $\beta>B$, a bank earns a higher asset risk premium that raises its excess portfolio rate of return by $\varphi_{M} \times(\beta$-B). These excess profits lower the bank's physical (real-world) expected portfolio losses but not its risk-neutral expected portfolio losses because the excess profits are only compensation for greater systematic risk. Consequently, for a given portfolio volatility $\sigma$, a higher asset portfolio $\beta$ chosen by the bank lowers its ratings-based minimum capital requirement, $K_{\min }$, even though its fair required capital is unchanged.

\subsection{Shareholder Value under Ratings-Based Regulation}

Following Marcus (1984) and Keeley (1990), we assume that shareholders’ equity reflects both the bank's residual tangible asset value plus a "charter value" equal to the value of excess profits from future operations. Let $E_{t}$ denote the value of the bank's shareholders' equity at date $t$. Its payoff at date $T$ is

$$
E_{T}=\left\{\begin{array}{cl}
A_{T}-D_{T} e^{p T}+C & \text { if } A_{T} \geq D_{T} e^{p T} \\
0 & \text { if } A_{T}<D_{T} e^{p T}
\end{array}\right.
$$

where $C$ is the bank's charter value that is lost if it fails at date $T$ and equals the value of rents from issuing 
future deposits. ${ }^{11}$ As detailed in Appendix A, the date 0 value of shareholders' equity can be written as

$$
E_{0}-\underbrace{K_{0}}_{\text {Capital }}=\underbrace{\operatorname{Put}\left(K_{0}+D_{0}, D_{T} e^{p T}, T\right)-e^{-r T} D_{T}\left(e^{p T}-1\right)}_{\text {Value of Mispriced Deposit Insurance }}+\underbrace{D_{0}\left(1-e^{-\left(r-r_{d}\right) T}\right)+e^{-r T} C N\left(d_{2}\right)}_{\text {Current and Future Charter Value }}
$$

Equation (6) shows that the market value of shareholders' equity equals the sum of initial capital, the value of a government deposit insurance subsidy, and the bank’s current and future charter value.

\subsection{Bank Choice of Capital and Systematic Risk}

Since our focus is on how ratings-based regulation affects systematic risk, we take as given the bank's asset portfolio volatility, $\sigma$. We also assume that the bank fixes the average rating of its portfolio's debt so that its ratings-based portfolio beta, $B$, is given. Further, suppose that regulators fix the deposit insurance rate, $p$, and set the bank's minimum capital requirement, $K_{\min }$, based on ratings according to equation (4). ${ }^{12}$ Importantly, note that equation (4) depends on the bank's true portfolio beta, $\beta$, which makes the ratingsbased minimum capital requirement a decreasing function of this beta, $K_{\min }(\beta)$.

Now consider the bank's choices of its initial capital, $K_{0}$, and its portfolio's true beta, $\beta$, where these choices satisfy $K_{\min }(\beta) \leq K_{0} \leq K_{\max }$ and $\beta_{\min } \leq \beta \leq \beta_{\max } \cdot{ }^{13}$ We assume the bank chooses $K_{0}$ and $\beta$ to maximize its shareholders' value in excess of its shareholders' contributed capital, which is the left hand side of equation (6). The following proposition gives the solution to the bank’s maximization problem.

Proposition: The choice of initial capital, $K_{0}$, and asset beta, $\beta$, that maximize the bank's shareholder value in excess of contributed capital, $E_{0}-K_{0}$, is either: i) $K_{0}=K_{\min }\left(\beta_{\max }\right)$ with $\beta=\beta_{\max }$; or ii) $K_{0}=K_{\max }$ with an indeterminate choice of $\beta$. For sufficiently small charter value $C$, the choice is $i$ ). Else, the choice is ii).

Proof: See Appendix A.

To understand this proposition, note from equation (6) that the bank’s excess shareholder value, $E_{0}-K_{0}$, comprises two components: the value of mispriced deposit insurance; and current and future charter value.

\footnotetext{
${ }^{11}$ Appendix A equation (A6) shows that $C=D_{0}\left(1-e^{-\left(r-r_{d}\right) T}\right) /\left(1-e^{-r T}\right)$.

${ }^{12}$ As mentioned earlier, in practice $p$ is largely risk-insensitive, but our qualitative results are unchanged as long as it does not vary with differences in systematic risk. Also note that if ratings were based on systematic risk so that $B=\beta$, then capital standards would be fair for any choice of $\sigma$.

${ }^{13}$ While $K_{\min }$ is given by equation (4), considerations outside of the model are assumed to determine the limits $K_{\max }$, $\beta_{\min }$, and $\beta_{\max }$. For example, a corporate tax disadvantage of equity may limit the bank's capital to $K_{\max }$ and technology and leverage limits may constrain borrowing firms' debt betas to be between $\beta_{\min }$ and $\beta_{\max }$.
} 
The bank faces a tradeoff when maximizing these two components because the first is a strictly decreasing function of initial capital while the second is a strictly increasing function of capital. When charter value that would be lost in bankruptcy, $C$, is large, the bank seeks to reduce its likelihood of failure by setting its initial capital at the maximum, $K_{0}=K_{\max }$. Instead, when $C$ is sufficiently small, excess shareholder value is maximized by exploiting the insurance subsidy and setting minimum capital. Now there would be no subsidy at this minimum if capital standards were set fairly according to equation (3). But the ratings-based standards in equation (4) permit the possibility of below-fair capital if the bank chooses high systematic risk. Hence, the bank's deposit insurance subsidy is maximized by choosing $K_{0}=K_{\min }\left(\beta_{\max }\right)$ and $\beta=\beta_{\max }$.

For simplicity, our preceding analysis took $B=\sum_{i=1}^{m} \omega_{i} B_{D, i}$ as given, but now suppose the bank can choose $\omega_{i}$. Note from equation (4) that a low charter value bank's insurance subsidy is a function of the difference $\left(\beta_{\max }-B\right)=\sum_{i=1}^{m} \omega_{i}\left(\beta_{D, i}^{\max }-B_{D, i}\right)$, where $\beta_{D, i}^{\max }$ is the maximum debt beta of firms in industry $i$. Taking a more general interpretation of $\omega_{i}$ as the bank's portfolio proportion allocated to asset class $i$, banks would prefer to invest in asset classes where the difference between the maximum debt beta and the debt beta that ratings-based regulation assigns to the class, $\left(\beta_{D, i}^{\max }-B_{D, i}\right)$, is greatest. This insight may explain why some banks heavily invested in highly-rated structured securities, such as MBS, which had low ratingsbased capital charges but inherently high systematic risk (Coval, Jurek, and Stafford (2009)). Nevertheless, for any asset class in which a low charter value bank invests (e.g., syndicated loans), our model predicts that the bank will choose the highest beta debt from among identically-rated debt.

\subsection{Implications for Yields on Identically-Rated Debt}

The preceding theory of regulatory arbitrage assumes that banks can choose a systematic risk for their loans and bonds, $\beta$, that exceeds the systematic risk implied by ratings-based capital requirements, $B$. Effectively, the bank earns a systematic risk premium of $\varphi_{M} \beta$ on its assets but its government-insured cost of funding charges only a premium of $\varphi_{M} B$. Consequently, as shown in equation (4), the bank's government subsidy is a function of the difference: $\varphi_{M}(\beta-B)$. 
A necessary condition for our theory of regulatory arbitrage is that the prices of default-risky loans and bonds reflect systematic risk premia but their credit ratings do not, at least not to the same extent. Theory such as Duffie and Singleton (1999) predicts that the yield on a default-risky debt, $y$, equals ${ }^{14}$

$$
\begin{aligned}
y & =r+P D^{Q} \times L G D^{Q} \\
& =r+P D \times L G D+\varphi_{M} \beta_{D}
\end{aligned}
$$

where $\beta_{D}$ is the debt's beta and $P D$ and $L G D$ are the debt's real-world annualized probability of default and proportional loss given default, respectively. Therefore, $P D \times L G D$ is the debt's annualized expected default losses. These variables with a $Q$ superscript reflect their risk-neutral counterparts. If credit ratings were based on risk-neutral expected default losses, $P D^{Q} \times L G D^{Q}$, it would be possible to set ratings-based capital requirements that preclude systematic risk arbitrage. Instead, if ratings are based primarily on real-world expected default losses, $P D \times L G D$, equation (7) indicates that arbitrage entails selecting from identicallyrated debt those bonds and loans with the highest debt betas, $\beta_{D}$. Such a choice is equivalent to "reaching for yield” by choosing this highest yielding debt of a given credit rating.

In the next section, we first empirically test whether yields on bonds and loans reflect systematic risk premia not incorporated in credit ratings. The following section then considers evidence for our model's prediction that low charter value banks choose low capital and high systematic risk.

\section{Credit Spreads, Credit Ratings, and Systematic Risk}

This section analyzes the yield equation (7) to test our model's assumption that same-rated debt yields are higher when the debt has higher systematic risk. Statements by credit rating agencies indicate that their ratings reflect corporate debt's real world probability of default or expected default losses, $P D \times L G D .{ }^{15}$ Yet, Hilscher and Wilson (2017) find evidence that a firm's (issuer's) credit rating is a better predictor of the firm's systematic risk of default than its real world default probability. However, we know of no research that uses yields and credit ratings on individual debt issues to test whether differences in yields, conditional on their ratings, are related to each debt issuer's systematic risk. We perform this test starting with a sample of corporate bonds. Following that, we consider a sample of syndicated loans.

\footnotetext{
${ }^{14}$ The Merton (1974) model's default risky debt yields also can be approximated as equation (7).

${ }^{15}$ See Moody's (2006). An exception is the new ratings criteria that S\&P announced during the financial crisis (Standard \& Poor's, 2008, 2010) that suggests it will take account of greater systematic risk: “Under S\&P's new criteria,... we may feel that two securities have similar default risk, but if we believe one is more prone to a sharp downgrade in periods of economic stress, it will be rated lower initially.” Moody’s has not announced a similar change.
} 


\subsection{Data and Variables for Corporate Bonds}

We obtained data from DCM Analytics on an international sample of corporate bonds issued over the years 1999 to 2010. These bonds are investment grade, fixed coupon, non-callable, non-convertible, nonperpetual, and non-government guaranteed. The data have information on each issuer (nationality, industry, etc.) and each bond's characteristics (years to maturity, face value, currency, etc.). It also contains each bond's issue credit rating and credit spread (the yield minus the yield on a government bond of the same currency and maturity). Since the ratings and spreads are both set at the time of issuance, they are ideal for testing whether they incorporate similar information. ${ }^{16}$ Based on each bond's ISIN codes, we obtain from Bloomberg the issuer's stock returns for the 52 weeks prior to the bond's issuance and the contemporaneous returns of the MSCI World Index. ${ }^{17}$ Our final sample is 3,924 bonds issued by 620 listed firms, mostly from North America, Europe, and Japan.

As the yield equation (7) suggests, the bond issuer's debt beta is a key variable in our analysis. Consistent with our model and Galai and Masulis (1976), the issuing firm’s date 0 debt beta equals

$$
\beta_{D}=N\left(-d_{1}\right) \frac{A_{0}}{D_{0}} \beta_{A}=\frac{E_{0}}{D_{0}} \frac{N\left(-d_{1}\right)}{N\left(d_{1}\right)} \beta_{E}
$$

where $A_{0}, D_{0}, E_{0}$ are current market values and $\beta_{A}, \beta_{D}, \beta_{E}$ are betas of the firm's assets, debt, and equity, respectively, $d_{1}=\left[\ln \left(A_{0} / X\right)+\left(r+\frac{1}{2} \sigma^{2}\right) \tau\right] /(\sigma \sqrt{\tau}), d_{2}=d_{1}-\sigma \sqrt{\tau}, \sigma$ is the firm's asset volatility, and $X$ is the promised payment on its debt to be paid in $\tau$ years. ${ }^{18}$

As detailed in Appendix B, we compute each bond issuer's debt beta using equation (8) and data on the issuer's market value of equity, the beta and total volatility of its stock returns, and balance sheet information on the issuer's debt. Similar to Marcus and Shaked (1984), the Merton (1974) model equations for each issuer's market value and volatility of equity are used to calculate the implied market value and volatility of the issuer's assets, $A_{0}$ and $\sigma$, respectively. Along with an estimate of the issuer's stock return beta, $\beta_{E}$, the issuer's debt beta in equation (8) can then be calculated. In the same fashion, we use an estimate of the residual volatility of the issuer's stock returns to compute the debt's residual volatility, which is a

\footnotetext{
${ }^{16}$ Other studies sometime use issuer ratings and secondary market bond spreads. Since ratings may become "stale” due to infrequent adjustments, new information may be reflected in secondary market spreads prior to ratings.

${ }^{17}$ Our main findings are robust to using the issuer's domestic stock index rather than the MSCI World Index.

${ }^{18}$ Our estimates of debt beta assume $\tau=10$ years, though the paper's results are robust to assuming a 5-year maturity.
} 
measure of the idiosyncratic risk of the firm's debt.

Our calculations of an issuer's debt beta and debt residual volatility only use the issuer's stock market and balance sheet information just prior to the bond issue. In principle, debt beta and residual volatility could be estimated from a time series of the bond's post-issuance returns. Yet many bonds are traded infrequently, leading to return series that can be stale and limited to low frequencies. Moreover, since our goal is to test whether a bond's new-issue credit spread reflects systematic risk beyond that of its issue rating, avoiding the use of future post-issuance information is critical. ${ }^{19}$

Table 1 provides mean values of some relevant issue and issuer characteristics by rating class (Panel A) and by year (Panel B). Panel A's summary statistics use broad letter ratings (AAA/Aaa, AA/Aa, A/A, and BBB/Baa), though our subsequent tests use finer notch-level ratings (AAA/Aaa, AA+/Aa1, AA/Aa2, etc.). As expected, the average credit spread at issuance increases monotonically as ratings worsen. It might seem surprising that issuers' of top-rated AAA/Aaa bonds also had higher debt betas and residual volatility compared to issuers of bonds with worse ratings. However, the majority of AAA/Aaa bonds (99 out of 132) were issued during 2008 and 2009 when systematic risk was abnormally high.

Panel B of Table 1 shows that the mean credit spread generally declined prior to the crisis but then rose from 2006 until 2009. The mean credit rating, equal to the average of Moody’s and S\&P’s rating converted into a numerical scale $(\mathrm{AAA} / \mathrm{Aaa}=1, \mathrm{AA}+/ \mathrm{Aa} 1=2, \ldots, \mathrm{BBB}-/ \mathrm{Bbb3}=10)$, show an opposite trend: the mean rating is 6.2 (about A/A2) during 1999 to 2005, while it is about one notch better (A+/A1) from 2006 through 2010. This pattern presumably reflects a "flight to quality" during the financial crisis when mainly high-quality issuers were able to tap debt markets.

Figure 1 shows the time series evolution of average debt betas of the issuing firms. From a level of 0.15 in 1999, debt betas steadily drop to 0.01 in years 2005 and 2006 and, then, dramatically increase to 0.22 in 2009. The rise reflects, in part, that a firm's debt beta increases as the market value of the firm's net worth declines. This is a consequence of the rise and fall of stock market capitalization and the debt beta equation (8): for a given asset volatility and beta ( $\sigma$ and $\beta_{A}$, respectively), as a firm's asset value declines relative to its promised debt payments, its debt's risk becomes closer to that of its assets. That is because a default, after

\footnotetext{
${ }^{19}$ Prior evidence suggests that our pre-issuance method of estimating a bond's debt beta produces an estimate close to that obtained from a post-issuance time series of returns on relatively liquid bonds. Schaefer and Strebulaev (2008) regress a corporation's monthly excess bond return on its excess stock (equity) return and find that the estimated sensitivities (coefficients) are similar to what is predicted by the Merton (1974) model on which our approach is based.
} 
which debtholders own the firm's assets, becomes more likely as assets decline.

\subsection{Do Bond Spreads Reflect Systematic Risk after Accounting for Ratings?}

Let us now examine whether spreads on identically-rated bonds reflect differences in systematic risk. Since prior studies find that liquidity also affects credit spreads, we generalize equation (7) to: ${ }^{20}$

$$
y-r=P D \times L G D+\varphi_{M} \times \beta_{D}+i p
$$

where ip is an illiquidity premium. Equation (9) motivates our empirical tests. Based on the idea that credit ratings primarily reflect real world expected default losses, we proxy $P D \times L G D$ by a series of nine dummy variables indicating the bond's issue rating at the notch level. ${ }^{21}$ In addition to the issuer's systematic risk as proxied by its debt beta, $\beta_{D}$, our regressions also include a measure of the debt's idiosyncratic risk as proxied by the log of its debt's residual volatility. We do this to see whether it is truly systematic risk, rather than the debt's overall risk, that is not accounted for by ratings.

Our regressions account for several issue and issuer control variables to proxy for the illiquidity premium, ip, as well as other possible factors affecting yields. ${ }^{22}$ These include the issue's face value, maturity, currency denomination, and the issuer's country and industry. A detailed description of all control variables is reported in Appendix C. In addition, for a subsample of our bonds we estimated another proxy for ip, namely, the bond's average relative bid-ask spread. This was done using bid and ask quotes from Bloomberg over the first 60 trading days following the bond's issuance. ${ }^{23}$ We were able to obtain these quotes for a subsample of 2,395 of the 3,924 total bonds.

Table 2 Column 1 reports the results of an OLS regression with robust standard errors clustered at both the year and the issuer level. It uses the full sample of bonds and shows that rating indicators are all strongly significant. The fact that the indicators' coefficients monotonically increase as the bond's rating worsens is evidence that corporate bond spreads and ratings embed some similar information on default risk. Yet, importantly, the coefficient on debt beta is also strongly significant while that of the debt's idiosyncratic

\footnotetext{
${ }^{20}$ Driessen (2005) estimates an average illiquidity premium of 21 basis points that varies with time and maturity.

${ }^{21}$ These variables are indicators for AA+/Aa1 , ..., BBB-/Bbb3, where AAA/Aaa is the excluded rating.

${ }^{22}$ For example, credit spreads may be affected by taxes that vary across countries.

${ }^{23}$ The relative bid-ask spread is computed as $100 \times($ Bid-Ask $) /[1 / 2($ Bid+Ask) $]$. Daily observations were deleted if the bidask spread was zero or negative. See Chordia et al. (2005) and Goyenco and Ukhov (2009).
} 
volatility is not. ${ }^{24}$ The debt beta coefficient of 105.4 implies that a one standard deviation increase in an issuer's debt beta of 0.136 raises the bond's credit spread by 14.3 bps. Since the regression's credit rating dummies imply that a worsening of one notch raises the credit spread by $15.7 \mathrm{bps}$, on average, this onestandard deviation higher debt beta impacts the spread only slightly less than would a notch downgrade.

Column 2 shows the results are robust to year-by-year Fama-MacBeth regressions, which effectively account for rating-by-time fixed effects. While the magnitudes of most coefficients are reduced, the effect of debt beta continues to be highly significant. Columns 3 and 4 report regressions similar to those in Columns 1 and 2, respectively, but using the subsample of bonds for which we could compute bid-ask spreads. The bid-ask spread is statistically significant, consistent with the presence of an illiquidity premium in bond spreads. Yet, the coefficient on debt beta continues to be significantly positive, and its magnitude is a bit larger than in the previous regressions. ${ }^{25}$

\subsection{Data and Variables on Syndicated Loans}

We use Loan Pricing Corporation's (LPC) DealScan database to investigate the effect of a borrowing firm's debt beta on the spread it pays on its loans at the time of the loan origination. DealScan reports each loan’s type (e.g., term loan or credit line), purpose (e.g., working capital, merger and acquisition), origination amount, origination date, maturity date, and the loan's interest rate spread over LIBOR.

The DealScan data is complemented with the loan's rating from Moody’s and, if unavailable, the loan's S\&P rating. Similar to the procedure described in Section 3.1 and Appendix B, a borrower's debt beta and debt residual volatility is computed using data from Compustat and the Center for Research on Securities Prices (CRSP) database. Use of information on each borrower's stock price restricts our analysis to publiclylisted firms.

After we merge these datasets we are left with a sample of 3,115 rated loans taken out by 918 corporations over the period 1995-2012. Table 3 provides summary statistics for this sample of loans. In contrast to the previous sample of international bonds, the majority of the syndicated loan sample is rated below investment grade, with an average rating of $\mathrm{BB} / \mathrm{Ba}$. In addition, the average credit spread is 224 basis points, as opposed to 115 basis points for the bond sample. The average maturity of 5.15 years is also

\footnotetext{
${ }^{24}$ The idiosyncratic volatility of the issuer's debt is insignificant presumably because it is fully captured by credit ratings. Indeed, in unreported results, we find that the coefficient of debt residual volatility becomes significant when rating dummies are excluded from the regression.

${ }^{25}$ Our findings are robust to regressions that use only Moody’s or only S\&P ratings. Results are available upon request.
} 
shorter than the mean 8.02 years for bonds. The borrowing firms' mean debt beta of 0.14 is higher than the 0.10 found for bonds. Yet as shown in Figure 2, the time series pattern for mean debt beta is similar by declining to a trough in 2005-2007 and reaching a peak in 2009.

\subsection{Do Loan Spreads Reflect Systematic Risk after Accounting for Ratings?}

To see whether syndicated loan credit spreads contain a systematic risk premium not accounted for by credit ratings, we rerun regression equation (9) using syndicated loan spreads as the dependent variable. We control for a set of loan characteristics, including size, maturity, loan purpose, credit type (e.g., credit line versus term loan), covenants, collateralization, and its credit rating. These controls are listed in Appendix C. Since there are relatively few syndicated loans rated A or above, we include AAA- AA- and A-rated loans as a single rating category and create rating dummy variables at the whole letter level. ${ }^{26}$

The regression results are reported in Table 4 and have some similarities to those for corporate bond spreads reported in Table 2. Table 4's Columns 1 and 2 report regressions with robust standard errors clustered at the year and issuer level while Columns 3 and 4 report year-by-year Fama-MacBeth regression results. In both types of regressions, loan credit spreads tend to be higher as credit ratings worsen. Yet credit ratings do not fully account for the borrower's systematic risk since the coefficient on debt beta is positive and significant in all of the regressions. Moreover, the magnitude of the debt beta coefficient is similar to that found for corporate bond spreads. One difference with loans is that their credit ratings appear to not fully account for the idiosyncratic risk of default. The results in Columns 2 and 4 show that when regressions include the log of residual volatility of the borrower's debt, it is also positively related to loan credit spreads.

In summary, syndicated loan spreads increase as credit ratings worsen. As with bonds, credit ratings fail to fully account for a spread's systematic risk premium as proxied by the borrower's debt beta. In addition, it appears that syndicated loan credit ratings fail to fully account for borrowers' idiosyncratic risks reflected in loan spreads, perhaps because idiosyncratic risks tend to be large and hard to estimate by rating agencies for the relatively credit-risky firms that borrow in the syndicated loan market.

\subsection{Do Credit Ratings Reflect Any Systematic Risk of Issuers?}

While not critical to our model's assumption that credit ratings fail to account for all of the systematic

\footnotetext{
${ }^{26}$ Including dummy variables for ratings at the notch level leads to many insignificant coefficients for rating notch dummies at the AA and A levels due to few observations. However, the effects of the coefficients on debt beta and debt residual volatility are virtually unchanged. Results are available upon request.
} 
risk reflected in credit spreads, this section investigates whether bond and syndicated loan ratings reflect any systematic risk. In particular, we examine whether an issuer's systematic risk can explain its bonds' and loans' ratings. Our main dependent variable in regressions is a bond or loan rating converted to a numerical scale $(\mathrm{AAA} / \mathrm{Aaa}=1, \mathrm{AA}+/ \mathrm{Aa} 1=2, \ldots, \mathrm{BBB}-/ \mathrm{Bbb} 3=10)$. For a bond, we use the average of Moody's and S\&P's ratings while for a syndicated loan we use its Moody's rating except when it is unavailable, in which case we use the S\&P loan rating. ${ }^{27}$

The regressions' explanatory variables include the issuer’s debt beta, the log of its debt's residual volatility, as well as control variables for the characteristics of the bond or loan. We run regressions with standard errors clustered at the year and issuer level as well as year-by-year Fama MacBeth regressions. Since use of a numerical scale for the rating implicitly assumes that ratings are cardinal measures so that risk differences between rating classes are the same, we also run an ordered probit regression for the loan or bond rating using the same explanatory variables. The results are reported in Table 5.

Panel A of Table 5 presents results for corporate bond ratings. Column 1 shows that debt beta is a significant predictor of a bond's rating when the debt's log of residual volatility is excluded. However, Column 2 shows that debt beta becomes insignificant when this proxy for idiosyncratic risk is included. Columns 3 and 4 repeat the same specifications used in Columns 1 and 2, respectively, but use the FamaMacBeth regression method. As Column 4 shows, when debt beta and residual volatility are jointly included, debt beta is marginally significant (at the $10 \%$ level) ${ }^{28}$ Both debt beta and residual volatility are positive and significant when an ordered probit regression is run.

Table 5’s Panel B reports the results of similar tests using syndicated loan ratings. In regressions where debt residual volatility is excluded as an explanatory variable, debt beta is positive and statistically significant. When we include debt residual volatility, its coefficient is always positive and significant, but the coefficient on debt beta is never significant. This finding is robust to all regression specifications, suggesting that syndicated loan ratings reflect idiosyncratic risk but not systematic risk. ${ }^{29}$

\footnotetext{
${ }^{27}$ Our results for bonds are robust to subsamples that use only Moody’s ratings or only S\&P ratings.

${ }^{28}$ The economic significance is small. The coefficient of 1.827 implies that a one standard deviation increase in debt beta worsens the rating by 0.197 of a notch $(=1.827 \times 0.1079)$. In contrast, the previous section's results show that a onestandard deviation increase in debt beta raised the bond spread by about one full notch.

${ }^{29}$ Table 5's general result that bond and syndicated loan credit ratings fail to incorporate systematic risk is not sensitive to the inclusion of control variables in the regressions. Indeed, in regressions where debt residual volatility is included, leaving out the control variables leads to a significantly negative relationship between bond and loan ratings and debt beta. Results are available upon request.
} 


\section{Empirical Evidence of U.S. Banks' Choice of Systematic Risk}

Having established that credit spreads on bonds and loans incorporate systematic risk premia that are not accounted for by the debts' credit ratings, we now consider whether banks actually exploit this phenomenon to engage in regulatory arbitrage. Our model predicts that low charter value banks choose low capital levels and assets with relatively high systematic risk. We consider two tests to investigate this prediction. The first test focuses on individual banks' selection of syndicated loans over the period 1995 to 2010. It analyzes whether low-capitalized banks select syndicated loans with more systematic risk than the loans chosen by high-capitalized banks. The second test goes beyond an investigation of individual syndicated loans and examines the systematic risk of a bank's total assets. It uses model-implied estimates of individual banks’ asset return betas and charter values over the period 2001 to 2014. This test analyzes whether low charter value banks chose asset portfolios with relatively high systematic risk.

Since both tests focus on U.S. banks, we need to consider the nature of U.S. risk-based bank regulations, and specifically ratings-based bank regulations, during our sample period. To that end, the next section discusses the history of risk-based deposit insurance and the record of risk-based capital regulations.

\subsection{Risk-Based Regulation of U.S. Banks}

To a large extent, Federal Deposit Insurance Corporation (FDIC) premiums have been unrelated to an individual bank’s risk. Rather, the FDIC has mostly adjusted the aggregate level of insurance premiums to target its Deposit Insurance Fund (DIF) reserves, a policy that is inconsistent with setting fair premia (Pennacchi (1999)). Indeed, because reserves were above the DIF target from 1996 to 2006, over 90\% of banks were charged a zero premium during this period. FDIC premiums were adjusted to cover DIF losses due to over 400 bank failures from 2007 to 2012, and in 2011 the FDIC’s method for setting premiums was revised. Under the new method, the average level of premiums is still set to target DIF reserves, but individual banks’ assessments may also reflect their real-world (physical) expected default losses. However, premiums do not penalize systematic risk by reflecting risk-neutral expected losses. ${ }^{30}$

The first formal risk-based capital standards for U.S. banks were implemented in 1992 in compliance

\footnotetext{
${ }^{30}$ See Federal Register 76 (38) February 25, 2011 which amends the Federal Deposit Insurance Act to comply with the Dodd-Frank Act. An underlying principle for setting premiums (assessments) is stated on page 10700: "Under the FDI (Federal Deposit Insurance) Act, the FDIC's Board of Directors must establish a risk-based assessment system so that a depository institution's deposit insurance assessment is calculated based on the probability that the DIF (Deposit Insurance Fund) will incur a loss with respect to the institution.” The FDIC's statistical failure probability models, on which its premium schedule is based, use physical, rather than risk-neutral, probabilities of bank failures.
} 
with the Basel I Accord. Basel I set minimum capital requirements based on a bank’s risk-weighted assets, but risk-weights were the same over very broad asset classes, such as all corporate bonds and loans. A 1996 Amendment to Incorporate Market Risks set capital standards for a large bank’s securities held in its "trading book.” These standards are calculated from a bank’s internal VaR model that is primary based on an estimated real-world distribution of security losses, rather than a risk-neutral one. Moreover, there is evidence that some banks used external credit ratings to calibrate their internal VaR models. ${ }^{31}$ In 2001, MBS and ABS securities held in a bank’s "banking book" became subject to capital requirements tied to the securities' external credit ratings. MBS and ABS tranches rated AAA to AA-, A+ to A-, BBB+ to BBB-, and $\mathrm{BB}+$ to BB- were assigned risk weights of $20 \%, 50 \%, 100 \%$, and $200 \%$, respectively.

Large U.S. banks were scheduled to be subject to Basel II capital standards starting in April 2008. However, the financial crisis starting in 2007 delayed its implementation, and these banks eventually transitioned from Basel I to the Basel III Internal Ratings-Based Approach (IRB) in January $2014 .{ }^{32}$ Under the IRB approach, credit risk capital charges are based on internal ratings generated from the single risk factor portfolio model analyzed in Gordy (2003). Inputs into the capital charge formula are the bank's own estimates of its bonds' and loans' physical probabilities of default $(P D)$ and losses given default $(L G D) .^{33}$ The Basel formula then converts these physical inputs into their hypothetical risk-neutral counterparts using an assumed beta or market correlation for each asset class. ${ }^{34}$ Importantly, this assumed beta (correlation) is not chosen by the bank but is set by Basel IRB rules and is essentially the same across very broad asset

\footnotetext{
${ }^{31}$ For example, in 2008 the Swiss Federal Banking Commission required that UBS report the key causes of its severe losses. UBS's report to shareholders (UBS, 2008) states that external credit ratings helped determine "the relevant product-type time series to be used in calculating VaR” (p. 20). Moreover, an over-reliance on credit ratings, which appears to be common in large banks, was found to be a primary cause of UBS's losses as "a comprehensive analysis of the portfolios may have indicated that the positions would necessarily perform consistent with their ratings” (p. 39). RiskMetrics also sometimes advocates basing VaR calculations on an issuer's rating. As stated in Mina and Xiao (2001, p.42) "For example, in marking-to-market a cash flow from an instrument issued by the U.S. Treasury, Treasury rates will be used, while for a cash flow from a Aa-rated financial corporate bond, the financial corporate Aa zero rate curve will be a good choice if a firm-specific zero rate curve is not available."

${ }^{32}$ IRB rules require sufficient initial capital, $K_{0}$, such that there is no more than a $0.1 \%$ physical probability of losses exceeding this initial capital over a one-year horizon. Credit risk weights for small U.S. banks remain the same as Basel I, with the exception MBS and ABS securities which have risk weights based on a "Simplified Supervisory Formula" described in http://www.federalreserve.gov/bankinforeg/basel/files/capital_rule_community_bank_guide_20130709.pdf ${ }^{33}$ There is a "Foundation" IRB approach where LGD is fixed for corporate claims. For example, it is $45 \%$ for all senior, unsecured bonds and loans. Under the "Advanced” IRB approach, guidelines recommend that banks estimate a bond or loan's “downturn” $L G D$ which reflects losses that are expected to occur if default happens during an economic downturn. In principle, use of downturn $L G D$ s may differentiate between high and low systematic risk claims, but since $P D$ s are not conditioned on a downturn, the VaR capital requirement is unlikely to fully incorporate systematic risk.

${ }^{34}$ Since $\omega_{i} \beta_{D, i}=\sigma_{A, i} \rho_{i, M} / \sigma_{M}$, where $\rho_{i, M}$ is the correlation between the market risk factor and the asset class $i$ 's return, an assumption regarding the correlation $\rho_{i, M}$ essentially is an assumption regarding the asset class's debt beta.
} 
classes. ${ }^{35}$ Hence, within an asset class, such as all corporate claims, there is no ability to differentiate between high and low systematic default risk for debt securities having the same $P D \times L G D$.

Banks appear to have adjusted their business models in response to changes in the Basel II and III IRB rules well before they were scheduled to be implemented. ${ }^{36}$ Moreover, while not formally part of risk-based capital rules, U.S. bank examiners have used external credit ratings to judge the risk of banks' holdings of securities. Harold (1938, p.25) reports that examiners at several different Federal Reserve banks evaluate their member banks’ bond portfolios using a method devised by Gustav Osterhus of the Federal Reserve Bank of New York. This method, detailed in Osterhus (1931), is a value-weighted average of external credit ratings converted to a numerical scale. Moreover, the Shared National Credit Program was created in 1977 to ensure that examiners by the three Federal banking regulators (Comptroller of the Currency, Federal Reserve, and FDIC) use a consistent regulatory credit rating for each syndicated loan that was held by multiple banks. Each loan was reviewed annually and given a rating by one of these regulators (FDIC 2004, 3.2-63). In addition, examiners would not give an adverse classification rating to any security that had an investment-grade external credit rating, unless the rating was stale (FDIC, 2004, 3.3-11).

In summary, there is ample evidence that regulators used credit ratings to evaluate bank risk, either formally or informally, for many decades. These ratings may have been set by external credit rating agencies, banks using internal VaR models, or the regulators themselves, but they share the general feature of being based on real-world (physical), rather than risk-neutral, expected default losses. Consequently, our empirical tests assume that banks were subject to ratings-based regulation throughout our sample periods.

\subsection{Banks’ Choice of Systematic Risk: Testable Hypotheses}

Our model in Section 2 predicts that ratings-based regulation gives banks with low charter value an incentive to minimize capital and invest in assets with the highest systematic risk; that is, they choose $\beta_{\max }$ and $K_{\min }\left(\beta_{\max }\right)$. An implication is that a bank's choice of systematic risk should be inversely related to its capital ratio and also inversely related to its charter value. For the set of regression equations

\footnotetext{
${ }^{35}$ The formula for assigning correlation values is the same for broad classes of corporate bonds and loans. These values can vary between $8 \%$ and $24 \%$, but the variation is a function only of the borrowing firm's annual sales (greater for firms with more than $€ 50$ million in sales) and the bank's estimated physical $P D$, where correlation is higher for lower PDs. See BCBS (2005). Fitch Ratings (2008) finds no empirical support for the IRB rule's inverse relationship between $P D$ s and portfolio correlation (systematic risk). As will be reported in our empirical work, neither do we find an inverse relationship between a firm's systematic risk (debt beta) and its probability of default (as reflected in its credit rating).

${ }^{36}$ For example, Plosser and Santos (2017) document that US banks began reducing their supply of so called 364-day facilities, which were targeted in Basel II, well before June 2004 when the Accord was finalized.
} 


$$
\begin{aligned}
& \text { SystematicRisk }_{i, t}=\alpha_{0}+\alpha_{1} \text { Capital }_{i, t-1}+\alpha_{2} \text { Controls }_{i, t-1}+\varepsilon_{i, t} \\
& \text { SystematicRisk }_{i, t}=a_{0}+a_{1} \text { Charter }_{i, t-1}+a_{2} \text { Controls }_{i, t-1}+\eta_{i, t},
\end{aligned}
$$

this prediction implies $\alpha_{1}<0$ and $a_{1}<0$, where SystematicRisk $k_{i, t}$ is the systematic risk of bank $i$ 's investments, Capital ${ }_{i, t}$ is bank $i$ 's capital ratio, and Charter $_{i, t}$ is bank $i$ 's charter value per deposit.

Our tests use both regression specifications due to the following tradeoffs. While equation (11) links systematic risk directly to charter value, charter value is not easily observable. Our method for estimating a bank's charter value, as well as the systematic risk of the bank's total assets, requires that the bank has both publicly-traded stock and CDS contracts. In contrast, our tests using capital ratios in equation (10) utilize a larger sample of banks that invest in syndicated loans. In this case, however, a bank's choice of systematic risk is based solely on its selection of different syndicated loans. We start with this case that uses regression (10), followed by a test based on equation (11) that examines banks' systematic risk of total assets.

\subsection{Banks' Choice of Syndicated Loan Systematic Risk}

To investigate how a bank’s selection of systematic risk relates to its capital ratio, we use two different measures of the systematic risk of the syndicated loans chosen by a bank at the end of the year that the loans were originated. The first measure is the weighted average of the debt betas of the borrowers to whom the bank granted syndicated loans, using the relative size of the bank's investment in each loan as weights. The second measure is motivated by the observation that the more systematically-risky loans of a given credit rating will have a higher spread. Accordingly, we calculate a weighted average excess spread on the bank's portfolio of loans instead of the weighted average of the debt betas of the bank's borrowers.

The weighted average excess spread is computed as follows. First, we calculate for each loan rating the weighted average spread of the new loans issued each year, with the weights determined by the size of the loan relative to all the loans issued in the year with the same rating. Next, we compute the excess spread for each loan as the difference between the spread on the loan and the weighted average spread of the loans with the same rating issued in that year. Finally, to calculate the weighted excess spread of the new loans chosen by a given bank during a particular year, we weight these excess spreads using the relative size of the bank's investment in each loan as weights. 
4.3.1 Data Information on banks' holdings of syndicated loans comes from the Shared National Credit (SNC) program run by the Federal Reserve, the Federal Deposit Insurance Corporation, and the Office of the Comptroller of the Currency. The SNC program gathers confidential data on new and existing credits that exceed $\$ 20$ million and are held by three or more federally-supervised institutions. As with DealScan, the SNC data contains information about the loan, including its size, maturity, purpose, credit type, origination and maturity date. In contrast to DealScan, the SNC data does not contain information on the loan interest rate, but, and importantly for our purposes, it contains complete information about the loan syndicate, including the share of the loan owned by the lead banks and the other participants. ${ }^{37}$ These loan shares correspond to each bank's loan holding as of the last day of each calendar year. Our second source of data is Federal Reserve Y9-C reports of individual bank holding company consolidated financial statements. This information provides each bank’s Tier I capital ratio and its total asset size.

After we merge datasets and require that information on each loan is recorded in SNC during the loan's origination year, that each loan's spread is available in DealScan, that the loan is rated, and that financial statement information is available on each bank investing in the loan, we are left with 5,046 loanbank observations. They correspond to 739 loans made by 165 different bank holding companies. After computing the weighted average excess spread for each bank during a given year, we obtain a total of 1,581 bank-year observations. To compute the weighted average debt beta for a given bank during a given year, we lose some observations due to the requirement that the borrowing firm have publically-traded equity. Thus, we are left with 1,177 bank-year observations when using debt beta as the systematic risk measure.

4.3.2 Results The two systematic risk measures for each bank are regressed on the bank's prior-year Tier 1 capital ratio, the bank’s size as proxied by the log of total assets, and controls for yearly fixed effects. Since a bank faces minimum capital requirements for both its Tier 1 capital to total assets (leverage) ratio and its Tier 1 capital to risk-weighted assets ratio, we consider regressions using these alternative capital ratio measures. ${ }^{38}$ Table 6 Panel A reports results using each bank’s Tier 1 capital to total assets ratio. Column 1 shows that the average debt beta of the syndicated loans chosen by a bank increases when its capital ratio is lower. Column 2 confirms this behavior even when the sample excludes the 2008 to 2010

\footnotetext{
${ }^{37}$ See Bord and Santos (2012) for a detailed comparison between these two loan databases.

${ }^{38}$ Acharya, Engle, and Pierret (2014) find that the Tier 1 capital to total assets measure has higher correlation with market measures of risk. On the other hand, the Tier 1 capital to risk-weighted assets measure may be more relevant for our model that predicts low charter value banks will choose a binding capital to risk-weighted assets ratio.
} 
crisis years. Moreover, the economic size of this effect is meaningful. For example, a one-standard deviation lower Tier 1 bank capital ratio of 2.02\% of assets raises the average debt beta of the bank's syndicated loans by $-2.02 \times(-0.0083)=0.016$. Given that the sample banks' weighted-average debt beta has a mean of 0.122 , the lower capital leads to a $13.7 \%$ increase in systematic risk.

Columns 3 and 4 of Table 6 Panel A report similar regressions but where the dependent variable is the average excess spread of the syndicated loans chosen by a bank. Consistent with the choice of higher debt beta, lower capital banks "reach for yield” by choosing syndicated loans with relatively high spreads given the loans' credit ratings. This reaching for yield behavior is present even when the 2008 to 2010 crisis years are excluded. As a robustness check, columns 5 and 6 repeat the regressions using a bank's choice of average excess loan spreads as the dependent variable, but restricting the sample to those loans for which the borrowing firm's debt beta could be calculated, which is the same sample used in the regressions reported in columns 1 and 2. In this case, lower capitalization has even a stronger effect on reaching for yield behavior. Overall, the coefficient estimates imply that a one standard deviation lower capital ratio raises a bank's credit-rating adjusted syndicated loan spreads by about 5 basis points.

Panel B of Table 6 repeats the same regressions as in Panel A but where each bank's capital ratio is its Tier 1 capital divided by risk-weighted assets. Using this alternative capital ratio measure produces no qualitative differences and hardly any quantitative differences. The only exception is for the excess spread regression using the whole sample, which is reported in column 3. There one sees that a lower ratio of capital to risk-weighted assets leads to a rise in the excess spread on syndicated loans that is twice the magnitude as that when the ratio of capital to total assets was used.

Note also that the results in Table 6 suggest that, ceteris paribus, a bank’s choice of systematic risk declines with bank size. Yet evidence that banks with low capital choose loans with higher debt betas and credit-rating adjusted spreads is strong and robust to different capital ratio measures. This behavior accords with our model's prediction that low charter value banks choose low capital and high systematic risk.

\subsection{Banks’ Choice of Asset Systematic Risk}

A limitation of the previous tests is that they consider only the syndicated loan portion of the bank's assets. To address this concern, in this section we examine a bank's choice of systematic risk at the level of its total asset portfolio. Each bank's asset systematic risk is related to its charter value using the regression 
equation (11). Estimates of a bank's asset systematic risk, $\beta_{A}$, and charter value per deposit, $C / D_{0}$, are those implied by our model in Section 2 and are inferred from data on each bank's value, volatility, and beta of shareholders' equity, as well as the CDS spread on its debt. The estimation methodology is similar to that detailed in Appendix B for nonbank corporations, but is now extended to three main equations instead of two. The first is the bank's market value of equity in equation (6) which can be rewritten as:

$$
E_{0}=A_{0} N\left(d_{1}\right)-e^{-r T} D_{T} e^{p T} N\left(d_{2}\right)+e^{-r T} C N\left(d_{2}\right) .
$$

The second equation is the volatility of the return on equity:

$$
\sigma_{E} \equiv \frac{\partial E_{0}}{\partial A_{0}} \frac{A_{0}}{E_{0}} \sigma=\left[N\left(d_{1}\right)+e^{-r T} C \frac{n\left(d_{2}\right)}{A_{0} \sigma \sqrt{T}}\right] \frac{A_{0}}{E_{0}} \sigma .
$$

The third equation expresses a CDS spread, $S_{C D S}$, as approximately equal to a default-risky credit spread: ${ }^{39}$

$$
S_{C D S} \approx y-r=P D^{Q} \times L G D^{Q}=\frac{N\left(-d_{2}\right)}{T} \times L G D^{Q} .
$$

Note that the market value and volatility of equity in equations (12) and (13) are functions of the bank's tangible assets, $A_{0}$, and its charter value, $C$. However, the bank's CDS spread in equation (14) depends only on tangible assets since charter value, by definition, is lost if the bank fails and defaults. This “exclusion restriction” helps us identify $C$ from $A_{0}$. Since equations (12) to (14) are functions of $C$, $A_{0}$, and the volatility of asset returns, $\sigma$, we can estimate these three variables given that all other variables in this nonlinear system are observable. Once we obtain values for $C, A_{0}$, and $\sigma$, as well as an estimate of the bank's stock return beta, $\beta_{E}$, an extension of Galai and Masulis (1979) allows us to estimate the bank’s asset return beta, $\beta_{A}$, as: ${ }^{40}$

$$
\beta_{A}=\beta_{E} /\left[\frac{\partial E_{0}}{\partial A_{0}} \frac{A_{0}}{E_{0}}\right]=\frac{\beta_{E} E_{0}}{A_{0} N\left(d_{1}\right)+e^{-r T} C \frac{n\left(d_{2}\right)}{\sigma \sqrt{T}}}
$$

\footnotetext{
${ }^{39}$ See Bomfim (2016) page 73 for a no-arbitrage argument that derives this result.

${ }^{40}$ At first glance, equation (15) might appear to impart a mechanical negative relationship between our estimate of asset systematic risk, $\beta_{A}$, and charter value, $C$, because $C$ appears in the denominator of the right-hand side of the equation. But that is not the case. Each bank-quarter estimate of $\beta_{A}$ is based on the bank-quarter's unique values of $E_{0}, \sigma_{E}$, and, $S_{C D S}$, which in turn produce unique bank-quarter values of $C, A_{0}$, and $\sigma$ using equations (12) to (14). Thus, $C$ cannot be considered fixed but, rather, is a function of several other variables: $C=C\left(E_{0}, \sigma_{E}, S_{C D S}, A_{0}, \sigma\right)$. Equivalently, from an inverse-function perspective, note that equation (12) implies that $E_{0}$ in the numerator of equation (15) is a positive function of $C$, so $C$ appears in both the numerator and denominator of equation (15).
} 
4.4.1 Data and Variables We implement this estimation using quarterly data on U.S. bank holding companies that had both publicly-traded shareholders' equity and CDS contracts over the period from 2001Q4 to 2014Q4. Market values of banks' shareholders' equity and stock returns were obtained from the Center for Research in Security Prices (CRSP) and end-of-quarter CDS spreads and estimated default recovery values are from IHS Markit. ${ }^{41}$ Quarterly bank holding company balance sheet data is from Federal Reserve Y-9C reports. After merging this data we obtain 1,059 bank-quarter observations representing 33 different bank holding companies. ${ }^{42}$ The estimation procedure outlined in the previous section is implemented to obtain each bank's asset return beta, $\beta_{A}$, and charter value per book-value of debt (deposits), $C / D_{0}$. More details of this estimation are given in the Appendix B.

Table 7 provides summary statistics of our main variables. Panel A includes all 33 bank holding companies. It shows that the mean asset return beta is 0.17 , which seems reasonable for assets that are mainly fixed-income securities and is comparable to the mean debt beta that we found in Table 3 for subinvestment-grade syndicated loans. The mean charter value-to-debt ratio is $4.1 \%$, with a maximum of $17.3 \%$ and a minimum very close to zero. ${ }^{43}$ These charter value estimates also seem plausible given the increasing level of competition from the deregulation of bank branching and the rise of nonbank competitors, such as money market funds. ${ }^{44}$

Seven of our sample's financial institutions became holding companies only during the recent financial crisis or were non-traditional banks in that their main subsidiaries were not commercial banks or thrift institutions. ${ }^{45}$ Thus, Panel B of Table 7 examines a subsample of 25 holding companies whose main subsidiary is a traditional bank. The summary statistics for this subsample are not much different, with the mean asset return beta being slightly smaller at 0.16 and the mean charter value-to-debt ratio being almost

\footnotetext{
${ }^{41}$ We use the spread on a 5-year CDS contract written on senior, unsecured debt.

${ }^{42}$ Note that there is approximately 8 years of quarterly data per holding company over this 14-year period. Several banks failed or were distressed acquisitions during 2008, including Washington Mutual, Wachovia, and National City.

${ }^{43}$ Our method of measuring charter value produces a lower average estimate than the method of Demsetz, Saidenberg, and Strahan (1996) and Boyson, Fahlenbrach, and Stulz (2016), which equals the sum of the bank's market value of equity plus book value of debt divided the book value of assets. Using their method, we find an average charter value to book asset ratio of $6.3 \%$ while our method's average, normalized by book assets rather than debt, is $3.9 \%$. The correlation between these two methods' estimates is 0.28 . We expect that our method would produce lower estimates because it accounts for the fact that the bank's market equity value reflects not only charter value but also a deposit insurance subsidy. It also does not assume that the market value of tangible assets equals the book value of assets.

${ }^{44}$ For example, data from the Investment Company Institute and FDIC show that the ratio of money market fund assets to total bank deposits was 5.1\%, 18.8\%, 44.1\%, and 47.4\% in 1980, 1990, 2000, and 2008, respectively.

${ }^{45}$ They are Charles Schwab, CIT Group, American Express, AIG, Morgan Stanley, Goldman Sachs, Metlife, and Discover Financial.
} 
identical at $4.1 \%$.

4.4.2 Results Table 8 reports the results of using this data with regression equation (11) where the dependent variable is quarterly observations of banks' asset return beta, $\beta_{A}$. The explanatory variable of interest is each bank’s ratio of charter value-to-debt. The regressions also include controls for bank size (log of total assets) and a measure of the bank's equity capital ratio. Columns (1) to (3) examine the subsample of only those 25 bank holding companies that have a traditional bank as their main subsidiary, and it uses each bank’s Tier 1 capital-to-total assets ratio as the capital ratio control. Column (1) presents regression results without any fixed effects, and its findings are consistent with the model prediction that banks with relatively low charter value have assets with significantly higher systematic risk. Column (2) shows results that control for bank fixed effects, which is a sensible adjustment since our sample ranges from small regional banks to large money-center banks. These banks have different business models that may lead to partly involuntary differences in systematic risk. The results with this control indicate an even stronger negative effect of charter value on a bank's choice of systematic risk.

The results are similar when we control for both bank and time (quarter) fixed effects. As shown in Column (3), the coefficient of -0.470 on charter value is statistically significant at the $1 \%$ confidence level. This point estimate is also economically significant. A one-standard deviation decline in charter value would raise a bank's asset beta by $0.470 \times 0.0476=0.0224$. Relative to the average bank asset beta of 0.1578 , this represents an asset beta increase to 0.1802 , a rise of $14.2 \%$. Of course higher asset betas imply more correlated asset returns, which could significantly raise the likelihood of simultaneous bank failures during an economic downturn. For example, if individual banks each had an unconditional probability of failure equal to $3 \%$ and asset betas of 0.1578 , the Vasicek (2002) portfolio model predicts that with $0.1 \%$ probability no more than $8.0 \%$ of banks would fail. ${ }^{46}$ Instead, if the banks' asset betas equaled 0.1802 , then with $0.1 \%$ probability no more than $9.0 \%$ of banks would fail. The implication is that at the $0.1 \%$ probability tail of the distribution, banks' higher systematic risk would increase the bank failure rate by $12.5 \%$.

Column (4) considers the entire sample that includes bank holding companies whose main subsidiary is not a traditional bank. Here we use the equity capital to total asset ratio as our control for capitalization

\footnotetext{
${ }^{46}$ This calculation is based on equation (4) in Vasicek (2002). Let $p$ be the unconditional probability that any single bank fails, and let $\beta_{A}$ be banks' asset beta. Then the probability that the proportion of banks that default, $b$, is less than $x$ equals $P(b \leq x)=N\left(\left[\sqrt{1-\beta_{A}^{2}} N^{-1}(x)-N^{-1}(p)\right] / \beta_{A}^{2}\right)$.
} 
since not all institutions report Tier 1 capital. The results are very similar to those of the subsample that included only traditional banks. There is a strong negative relationship between charter value and systematic risk-taking. There also appears to be a positive relationship between capital and systematic risk when we control for charter value and bank and time fixed effects. Perhaps if low charter value banks are subject to minimum risk-based capital requirements, they need to increase the risk of their assets in order to invest in default-risky loans and securities that have high systematic risk. That might explain why capital ratios that are not risk-weighted may need to rise.

To see if the results are robust to excluding the volatile financial crisis years of 2008 and 2009, we run regressions excluding all observations in these two years. Table 8 Column 5 reports the regression using only traditional banks while Column 6 includes all bank holding companies. The main results are unchanged though significance is somewhat weaker for the traditional bank subsample. Overall, these results are consistent with our theory which predicts that when a bank's failure entails relatively little lost charter value, the bank is more likely to exploit its government safety net by taking high systematic risk.

\subsection{Equilibrium Implications}

The single bank model in Section 2 could be extended to consider the market structure of the banking industry. Keeley (1990) argues that starting in the 1970’s, deregulation and the entry of nonbanks, such as money market mutual funds, led to greater competition that reduced banks' charter values. An implication of greater competition is an increase in ratings-based regulatory arbitrage as more banks switch from a strategy of protecting their declining charter value to exploiting their deposit insurance subsidy. The previous section's empirical evidence is consistent with this switching given it shows that lower charter value raises the systematic risk of a bank’s assets.

If, for a given credit rating, regulatory arbitrage generates a greater demand for high beta debt, there could be a corresponding increase in supply. The growth in highly-rated, but systematically-risky, structured securities over the last few decades (Coval, Jurek, and Stafford, 2009) may be an example. Yet with some inelasticity in supply, an extraordinary demand for systematically-risky debt has equilibrium pricing implications: controlling for rating, the yields on high beta debt would fall relative to the yields on low beta debt. The effect in terms of the credit spread equation (9) is a decline in the market price of systematic risk, $\varphi_{M}$, commonly referred to as the "equity premium.” 
The results of our credit spread regressions reported in Tables 2 and 4 provide estimates of $\varphi_{M}$ equal to the coefficient on debt beta. Depending on the specification, our estimates of $\varphi_{M}$ range from 83 to 139 basis points for bonds and from 42 to 109 basis points for syndicated loans. ${ }^{47}$ Clearly, these estimates are less than the historical excess return on U.S. equities. ${ }^{48}$ Undoubtedly, one reason for our low estimates is due to errors when estimating each issuing firm’s debt beta, $\beta_{D}$, which downward biases our estimate of $\varphi_{M}{ }^{49}$ However, a low value of $\varphi_{M}$ is also consistent with our theory and empirical evidence that ratings-based regulation generates an extraordinary demand for high beta debt. ${ }^{50}$ Note that even if systematic risk-taking is not highly rewarded in terms of risk premia, it could be attractive to banks for another reason. By herding into a systematically-risky common exposure, banks may increase the likelihood that the government bails out the banking industry (Penati and Protopapadakis (1988), Acharya and Yorulmazer (2007)).

Interestingly, early tests of the CAPM based on a time series of stock returns, such as Black, Jensen, and Scholes (1972) and Fama and MacBeth (1973), estimated values for $\varphi_{M}$ that were positive but also below the historical excess market return. Moreover, tests using more recent stock return data produce even lower estimates. Fama and French (1992) estimate that $\varphi_{M}$ is essentially zero during 1963 to 1990 . Baker, Bradley, and Wurgler (2011) show that low beta stocks outperformed high beta stocks over the period 1968 to 2008, implying a strictly negative value for $\varphi_{M} \cdot{ }^{51}$

Several theories have been proposed to explain this extraordinary demand for high beta stocks, including restricted borrowing by investors (Black, 1972 and Frazzini and Pedersen, 2014), mutual fund

\footnotetext{
${ }^{47}$ By allowing $\varphi_{M}$ to vary over time, our Fama-MacBeth regression estimates indicate that during the 2008-2010 financial crisis years, it averaged 365 basis points for bonds and 189 basis points for loans.

${ }^{48}$ From 1926 to 2016, the continuously-compounded return on the CRSP value-weighted index in excess of a onemonth Treasury bill return was 5.93\%. Another estimate of expected excess stock market returns is available from annual forecasts by the Survey of Professional Forecasters. Their 10-year prediction for the return on the S\&P500 versus the 3-month Treasury rate implies equity premiums averaging 3.65\% during the 1999 to 2010 period. See http://www.phil.frb.org/research-and-data/real-time-center/survey-of-professional-forecasters/ .

${ }^{49}$ As the number of observations increase, the true value of $\varphi_{M}$ converges to $\left(1+\sigma_{\varepsilon}^{2} / \sigma_{\beta}^{2}\right)$ times its estimated value, where $\sigma_{\varepsilon}^{2}$ is the variance of estimation errors and $\sigma_{\beta}^{2}$ is the variance of the true $\beta_{D}$ 's. Note that the standard practice when estimating $\varphi_{M}$ from a time series of stock returns is to sort stocks into portfolios based on their estimated beta in a prior period. This method is not applicable to our data that contains a single observation for each bond or loan at the date it is issued.

${ }^{50}$ Murray and Nikolova (2017) use a time series of returns on corporate bonds to estimate their betas for an aggregate default factor and a default-free term structure factor. Consistent with underpriced systematic risk, they find that debt with high term structure betas underperform relative to similarly-rated debt with low term structure betas. Also, consistent with insurance company regulation that requires a steep capital charge for sub-investment grade bonds, bonds rated marginally investment grade (BBB-) are underpriced relative to higher-rated bonds.

${ }^{51}$ Frazzini and Pedersen (2011) also find a negative reward for bearing systematic risk using several asset classes, including 20 international equity markets.
} 
managers that exploit investors’ returns-chasing behavior (Karceski, 2002), fixed-benchmark mandates for money managers that limit arbitrage (Baker et al. 2011), and investors who disagree but face short-sale constraints (Hong and Sraer, 2016).

Obviously, our theory and empirical evidence for systematic risk-taking is distinctly different. It is specific to debt securities held by financial institutions, such as banks and insurance companies, that are subject to ratings-based regulation. Our finding of a small but positive reward for systematic risk-taking in debt markets contrasts with existing studies that find a negative reward for systematic risk in stock markets and suggests some degree of market segmentation.

\section{Conclusions}

Our model shows that when bond and loan credit spreads embed systematic default risk premia that are absent from these debts' credit ratings, ratings-based regulation leads low-charter value banks to minimize capital and take high systematic risks. A worrisome implication of these choices is that by loading on systematic risk, low-capitalized banks become more likely to fail simultaneously during market downturns, exacerbating systemic risk. Complementing a previous literature that emphasized the high systematic risk of structured securities, we find evidence of economically significant systematic risk in corporate debt: credit spreads on identically-rated corporate bonds and loans are significantly higher when their issuers have greater systematic default risk.

We also present direct evidence that systematic moral hazard occurs among U.S. commercial banks. First, we show that low-capitalized banks choose syndicated loans with relatively high debt betas and relatively high spreads given the loans' ratings. Second, we derive model-implied estimates of banks' charter values and asset return betas and confirm our model's prediction that banks with relatively low charter value choose assets whose returns have relatively high systematic risk.

Since 2009, reforms to bank and insurance company capital requirements have concentrated on structured securities and largely ignored corporate debt. ${ }^{52}$ With greater risk weights on structured securities, corporate bonds and loans might now be the preferred vehicle for these institutions to engage in regulatory arbitrage. Our empirical finding of significant variation in corporate systematic risks shows that there

\footnotetext{
${ }^{52}$ Under Basel III, the Basel Committee (2009) has reformed risk weights for securitizations and raised them for resecuritizations (e.g., CDOs) under both the Standardized approach and for the IRB approach. Thus far, Basel III recommends no major changes for risk weights on corporate claims relative to the standards set before the crisis.
} 
remains scope for exploitation of ratings-based regulation.

What regulatory reforms might address this moral hazard? One remedy is to reduce the distortions by increasing market discipline (Flannery (1998)). When a bank obtains subordinated funding from investors who are not de jure or de facto insured by a government, the uninsured debt's credit spread should account for the bank's systematic risk and act as a deterrent. ${ }^{53}$ In turn, regulatory capital requirements and supervisory actions might better respond to systematic risk if they were linked to the credit spreads or credit default swap spreads of the bank's uninsured debt, as Hart and Zingales (2011) advocate. Finally, more emphasis on setting capital requirements based on the outcome of stress tests is a welcomed development. ${ }^{54}$ By focusing on performance during severe economic downturns, the most systematically risky banks might be targeted for greater required capital.

\footnotetext{
${ }^{53}$ In our model if an intermediary issued uninsured debt, its credit spread, $p$, would satisfy the fair standard equation (3). One approach to implement greater market discipline would be to narrow the scope of activities that could be funded by insured liabilities. Non-qualifying activities would need to be funded with uninsured funds in separate subsidiaries or separate firms. Examples of this approach are the 2010 Dodd-Frank Act's "Volker Rule" that bars proprietary trading by banks, the 2011 U.K. Independent Commission on Banking's (Vickers) proposal to restrict deposit-insured banks to "ring-fenced" retail and payments-related activities, and the 2012 European Commission HighLevel Expert Group (Liikanen) Report’s proposal to restrict propriety trading and other risky activities non-bank, uninsured subsidiaries.

${ }^{54}$ Examples include the U.S.'s Comprehensive Capital Analysis and Review (CCAR) and the European Central Bank's and European Banking Authority's EU-wide stress tests.
} 


\section{References}

Abramowitz, M., and Stegun, I., 1972. Handbook of Mathematical Functions. (10 ${ }^{\text {th }}$ printing). Dover Publications, New York.

Acharya, V., Engle, R., and Pierret, D., 2014. Testing Macroprudential Stress Tests: The Risk of Regulatory Risk Weights. Journal of Monetary Economics 65, 36-53.

Acharya, V., Schnabl, P., and Suarez, G., 2013. Securitization without Risk Transfer. Journal of Financial Economics 107, 515-536.

Acharya, V., and Steffen, S., 2015. The “Greatest” Carry Trade Ever? Understanding Eurozone Bank Risks. Journal of Financial Economics 115, 215-236.

Acharya, V., and Yorulmazer, T., 2007. Too Many to Fail - An Analysis of Time-Inconsistency in Bank Closure Policies. Journal of Financial Intermediation 16, 1-31.

Baker, M., Bradeley, B., and Wurgler, J., 2011. Benchmarks as Limits to Arbitrage: Understanding the LowVolatility Anomaly. Financial Analysts Journal 67, 1-15.

Basel Committee on Banking Supervision, 2005. An Explanatory Note on the Basel II IRB Risk Weight Functions. Bank for International Settlements. 2009. Enhancements to the Basel II framework. Bank for International Settlements.

Becker, B., and Ivashina, V., 2015. Reaching for Yield in the Bond Market. Journal of Finance 70, 18631901.

Black, F., 1972. Capital Market Equilibrium with Restricted Borrowing. Journal of Business 4, 444-455.

Black, F., Jensen, M., and Scholes, M., 1972. The Capital Asset Pricing Model: Some Empirical Tests. In Studies in the Theory of Capital Markets, M. Jensen, Ed., Praeger, New York.

Bomfim, A., 2016. Understanding Credit Derivatives and Related Instruments, $2^{\text {nd }}$ Ed., Academic Press, Waltham, MA.

Bord, V., and Santos, J., 2012. The Rise of the Originate-to-Distribute Model and the Role of Banks in Financial Intermediation. Federal Reserve Bank of New York Policy Review (July), 21-34.

Boyson, N., Falhenbrach, R., and Stulz, R., 2016. Why Don’t All Banks Practice Regulatory Arbitrage? Evidence from Usage of Trust-Preferred Securities? Review of Financial Studies 29, 1821-1859.

Brown, J., 2010. Public Insurance and Private Markets, AEI Press, Washington, D.C. 
Chernenko, S., Hanson, S., and Sunderam, A., 2014. The Rise and Fall of Securitization. Harvard University and Ohio State University working paper.

Chordia, T., Sarkar, A., and Subrahmanyam, A., 2005. An Empirical Analysis of Stock and Bond Market Liquidity. Review of Financial Studies 18, 85-129.

Collin-Dufresne, P., Goldstein, R., and Martin, J., 2001. The Determinants of Credit Spread Changes. Journal of Finance 56, 2177-2207.

Collin-Dufresne, P., Goldstein, R., and Yang, F., 2012. On the Relative Pricing of Long-Maturity Index Options and Collateralized Debt Obligations. Journal of Finance 67, 1983-2014.

Coval, J., Jurek, J., and Stafford, E., 2009. Economic Catastrophe Bonds. American Economic Review 99, 628-666.

Cummins, J.D., 1988. Risk-based Premiums for Insurance Guaranty Funds. Journal of Finance 43, 823-839.

Demsetz, R., Saidenberg, M., and Strahan, P., 1996. Banks with Something to Lose: The Disciplinary Role of Franchise Value. Federal Reserve Bank of New York Policy Review October, 1-14.

Driessen, J., 2005. Is Default Event Risk Priced in Corporate Bonds? Review of Financial Studies 18, 165195.

Duffie, D., and Singleton, K., 1999. Modeling Term Structures of Defaultable Bonds. Review of Financial Studies 12, 687-720.

Efing, M., 2015. Arbitraging the Basel Securitization Framework: Evidence from German ABS Investment. Deutsche Bundesbank Discussion Paper No. 40/2015.

Elton, E., Gruber, M., Agrawal, D., and Mann, C., 2001. Explaining the Rate Spread on Corporate Bonds. Journal of Finance 56, 247-277.

Fama, E., and French, K., 1993. Common Risk Factors in the Returns on Stocks and Bonds. Journal of Financial Economics 33, 3-57.

Fama, E., and MacBeth J., 1973. Risk, Return and Equilibrium: Empirical Tests. Journal of Political Economy 81 (3), 607-636.

Federal Deposit Insurance Corporation, 2004. DSC Risk Management Manual of Examination Policies, Division of Supervision and Consumer Protection. 
Fitch Ratings, 2008. Basel II Correlations Values. Credit Market Research Financial Institutions Special Report.

Flannery, M., 1998. Using Market Information in Prudential Bank Supervision: A review of the U.S. empirical evidence. Journal of Money, Credit and Banking 30, 273-305.

Frazzini, A., and Pedersen, L., 2014. Betting Against Beta, Journal of Financial Economics 111, 1-25.

Galai, D., and Masulis, R., 1976. The Option Pricing Model and the Risk Factor of Stock. Journal of Financial Economics 3, 53-81.

Gordy, M., 2003. A Risk-Factor Model Foundation for Ratings-Based Bank Capital Rules. Journal of Financial Intermediation 12, 199-232.

Gornall, W., and Strebulaev, I., 2017. Finance as a Supply Chain: The Capital Structure of Banks and Borrowers. Journal of Financial Economics (forthcoming).

Goyenco, A.D., and Ukhov, R.Y., 2009. Stock and Bond Market Liquidity: A Long-Run Empirical Analysis. Journal of Financial and Quantitative Analysis 44, 189-212.

Harold, G., 1938. Bond Ratings as an Investment Guide: An Appraisal of their Effectiveness. The Ronald Press Company, New York.

Hart, O., and Zingales, L., 2011. A New Capital Regulation for Large Financial Institutions. American Law and Economics Review 13, 453-490.

Hilscher J., and Wilson, M., 2017. Credit Ratings and Credit Risk: Is One Measure Enough?, Management Science 63, 3414-3437.

Hull, J., M. Predescu, and A. White, 2005. Bond Prices, Default Probabilities, and Risk Premiums. Journal of Credit Risk 1(2), 53-60.

Kareken, J. and Wallace, N., 1978. Deposit Insurance and Bank Regulation: A Partial-Equilibrium Exposition. Journal of Business 51, 413-438.

Karceski, J., 2002. Returns-Chasing Behavior, Mutual Funds, and Beta’s Death, Journal of Financial and Quantitative Analysis 37, 559-594.

Keeley, M., 1990. Deposit Insurance, Risk, and Market Power in Banking. American Economic Review 80, 1183-1200. 
Kupiec, P., 2004. Is the New Basel Accord Incentive Compatible? In: Gup, B. (Ed.), The New Basel Capital Accord. Thompson South-Western Publishers.

Marcus, A., 1984. Deregulation and Bank Financial Policy. Journal of Banking and Finance 8, 557-565.

Marcus, A., and Shaked, I., 1984. The Valuation of FDIC Deposit Insurance Using Option-Pricing Estimates. Journal of Money, Credit and Banking 16, 446-460.

Merton, R., 1974. On the Pricing of Corporate Debt: The Risk Structure of Interest Rates. Journal of Finance 29, 449-470.

Merton, R., 1977. An Analytic Derivation of the Cost of Deposit Insurance and Loan Guarantees: An Application of Modern Option Pricing Theory. Journal of Banking and Finance 1, 3-11.

Merton, R., 1978. On the Cost of Deposit Insurance When There Are Surveillance Costs. Journal of Business $51,439-452$.

Merrill, C., Nadauld, T., and Strahan, P., 2014. Final Demand for Structured Finance Securities. Management Science (forthcoming).

Mina, J., and Xiao, J.Y., 2001. Return to RiskMetrics: The Evolution of a Standard. RiskMetrics Technical Document.

Moody’s Investor Service (2006). Probability of Default Ratings and Loss Given Default Assessments for Non-Financial Speculative-Grade Corporate Obligors in the United States and Canada. Ratings Methodology Report (August).

Murray, S., and Nikolova, S., 2017. The Bond Pricing Implications of Ratings-Based Capital Requirements, Georgia State University and University of Nebraska working paper.

Nagel, S., and Purnanandam, A., 2017. Bank Risk Dynamics and Distance to Default. University of Michigan working paper.

Osterhus, G., 1931. Flaw-Tester for Bond Lists. American Bankers Association Journal 24 (August), 67-68, $110-111$.

Penati, A., and Protopapadakis, A., 1988. The Effect of Implicit Deposit Insurance on Banks’ Portfolio Choices with an Application to International Overexposure. Journal of Monetary Economics 21, $107-126$. 
Pennacchi, G., 1999. The Effects of Setting Deposit Insurance Premia to Target Insurance Fund Reserves. Journal of Financial Services Research 16, 63-90.

Pennacchi, G., 2006. Deposit Insurance, Bank Regulation, and Financial System Risk. Journal of Monetary Economics 53, 1-30.

Plosser, M., and Santos, J., 2017. The Cost of Bank Regulatory Capital, mimeo, Federal Reserve Bank of New York.

Hong, H., and Sraer, D., 2016. Speculative Betas, Journal of Finance 71, 2095-2143.

Schaefer, S., and Strebulaev, I., 2008. Structural Models of Credit Risk Are Useful: Evidence from Hedge Ratios on Corporate Bonds. Journal of Financial Economics 90, 1-19.

Standard \& Poor’s, 2008. General Criteria: Standard \& Poor’s to Explicitly Recognize Credit Stability as an Important Rating Factor. (October 15) Available at www.standardandpoors.com.

Standard \& Poor's, 2010. General Criteria: Methodology: Credit Stability Criteria. Available at www.standardandpoors.com.

UBS, 2008. Shareholder Report on UBS’s Write-Downs. Available at www. ubs.com.

Vasicek, O., 2002. The Distribution of Loan Portfolio Value. RISK 15, 160-162. 


\section{APPENDIX A - Model Details}

Return on Bank Assets: The model in Section 2 considers a bank whose assets are a fixed-income portfolio composed of corporate debt issued by many different firms. Each firm's capital structure satisfies the model of Merton (1974). Specifically, if firm $i$ has date $t$ assets worth $A_{i, t}$ and issues of a single zero-coupon bond or loan that promises to pay $X_{i}$ in $\tau_{i}$ periods, then the date $t$ value of firm i's debt, $D_{i, t}$, equals

$$
D_{i, t}=A_{i, t} N\left(-d_{1, i}\right)+X_{i} e^{-r \tau_{i}} N\left(d_{2, i}\right)
$$

where $d_{1, i}=\left[\ln \left(A_{i, t} / X_{i}\right)+\left(r+\frac{1}{2} \sigma_{i}^{2}\right) \tau_{i}\right] /\left(\sigma_{i} \sqrt{\tau_{i}}\right), d_{2, i}=d_{1, i}-\sigma_{i} \sqrt{\tau_{i}}$, and $\sigma_{i}$ is the volatility of the return on firm $i$ 's assets. The standard deviation of the return on this default risky debt, $\sigma_{d, i}\left(\tau_{i}\right)$, equals

$$
\sigma_{d, i}\left(\tau_{i}\right)=N\left(-d_{1, i}\right) \frac{A_{i, t}}{D_{i, t}} \sigma_{i}
$$

which changes over time. However, the bank is assumed to hold the risky debt of other firms in the same industry that have assets driven by the same Brownian motion as that of firm $i$, say $d z_{i}$. By buying and selling bonds of industry $i$ firms and/or making new loans and not renewing maturing loans to those firms, the bank can keep its total assets' relative exposure to this industry constant, equal to $\sigma_{\mathrm{A}, i}$. For example, if the average volatility of the debt of industry $i$ held by the bank equals $\bar{\sigma}_{i}$ and its total asset portfolio weight to industry i's debt is $\omega_{i}$, then the bank adjusts $\omega_{i}$ and $\bar{\sigma}_{i}$ to keep $\sigma_{A, i}=\omega_{i} \bar{\sigma}_{i}$ constant. If it holds debt of firms in $m$ different industries, the bank's re-balancing implies that its total assets satisfy equation (1) in the text.

Maintaining the Merton (1974) assumptions and also assuming there is a single priced risk factor consistent with the CAPM, let the economy's stochastic discount factor be of the form $d M_{t} / M_{t}=-r d t$ $\theta d z_{M}{ }^{55}$ Then the expected rate of return on the bank's total asset portfolio is

$$
\mu=r+\theta \sum_{i=1}^{m} \sigma_{A, i} \rho_{i, M}
$$

where $d z_{i} d z_{M}=\rho_{i, M} d t$ and $\theta=\varphi_{M} / \sigma_{M}$ is the Sharpe ratio of the market portfolio, equal to the expected excess return on the market portfolio, $\varphi_{M}$, divided by the market portfolio’s standard deviation of return, $\sigma_{M}$. Thus, from equation (A3), the bank portfolio's expected rate of return equals equation (2) in the text where $\beta_{D, i}=$

\footnotetext{
${ }^{55}$ It is straightforward to extend the model to an economy with multiple risk factors.
} 
$\bar{\sigma}_{i} \sigma_{M} \rho_{i, M} / \sigma_{M}^{2}$ is the debt beta of the average firm in industry $i$.

Value of Bank Shareholders' Equity: The date 0 value of the date $T$ payoff to equity in equation (5) is analogous to a call option written on the bank's tangible assets, $A_{0}=D_{0}+K_{0}$, with an exercise price of $D_{T} e^{p T}$ $=D_{0} e^{\left(r_{d}+p\right) T}$, plus the discounted future charter value times the risk-neutral probability of not defaulting:

$$
\begin{aligned}
E_{0} & =\left(K_{0}+D_{0}\right) N\left(d_{1}\right)-e^{-r T} D_{T} e^{p T} N\left(d_{2}\right)+e^{-r T} C N\left(d_{2}\right) \\
& =K_{0}+D_{0}-\left(K_{0}+D_{0}\right) N\left(-d_{1}\right)-e^{-r T} D_{T} e^{p T} N\left(d_{2}\right)+e^{-r T} C N\left(d_{2}\right)
\end{aligned}
$$

Adding and subtracting the value of premiums, $e^{-r T} D_{T}\left(e^{p T}-1\right)=D_{0} e^{-\left(r-r_{d}\right) T}\left(e^{p T}-1\right)$, from the right-handside of (A4) and re-arranging terms we obtain:

$$
\begin{aligned}
E_{0}= & K_{0}+e^{-r T} D_{T} e^{p T} N\left(-d_{2}\right)-\left(K_{0}+D_{0}\right) N\left(-d_{1}\right)-e^{-r T} D_{T}\left(e^{p T}-1\right) \\
& +D_{0}\left(1-e^{-\left(r-r_{d}\right) T}\right)+e^{-r T} C N\left(d_{2}\right)
\end{aligned}
$$

By noting that the second and third terms on the right-hand-side of (A5) equal the value of a put option written on bank assets with an exercise price of $D_{T} e^{p T}$, we obtain equation (6) in the text. Now note that $D_{0}\left(1-e^{-\left(r-r_{d}\right) T}\right)$ is the one-period value of being able to issue deposits at the below-competitive rate $r_{d}$, rather than the competitive rate $r$. The date $T$ value of continuing to issue the amount $D_{0}$ of deposits at rate $r_{d}$ for all future periods of length $T$ starting at date $T$ is

$$
C=D_{0}\left(1-e^{-\left(r-r_{d}\right) T}\right) \sum_{i=0}^{\infty} e^{-r T \times i}=D_{0}\left(1-e^{-\left(r-r_{d}\right) T}\right) \frac{1}{1-e^{-r T}}
$$

Proof of Proposition: The bank is assumed to maximize shareholders' equity in excess of shareholders' contributed capital, $E_{0}-K_{0}$, which is equation (6) and equals the value of the bank's deposit insurance subsidy plus the present value of its charter. The bank chooses $K_{0}$ and $\beta$ subject to the constraints $K_{\min }(\beta) \leq$ $K_{0} \leq K_{\max }$ and $\beta_{\min } \leq \beta \leq \beta_{\max }$ where $K_{\min }(\beta)$ satisfies the credit rating-based minimum capital requirement in (4). Note that in (4), $K_{\min }$ and $\beta$ appear only through the term $\left(K_{\min }+D_{0}\right) e^{\varphi_{M}(\beta-B) T}$, so that when (4) is satisfied, we have $d K_{\min } / d \beta=-\varphi_{M} T\left(K_{\min }+D_{0}\right)<0$, implying that $K_{\min }(\beta)$ is minimized at $\beta=\beta_{\max }$. The Lagrangian of the bank's maximization problem is 


$$
\begin{aligned}
L= & e^{-r T} D_{T} e^{p T} N\left(-d_{2}\right)-\left(K_{0}+D_{0}\right) N\left(-d_{1}\right)-e^{-r T} D_{T}\left(e^{p T}-1\right)+D_{0}\left(1-e^{-\left(r-r_{d}\right) T}\right)+e^{-r T} C N\left(d_{2}\right) \\
& +\lambda_{1}\left(K_{\max }-K_{0}\right)+\lambda_{2}\left(K_{0}-K_{\min }(\beta)\right)+\lambda_{3}\left(\beta_{\max }-\beta\right)+\lambda_{4}\left(\beta-\beta_{\min }\right)
\end{aligned}
$$

and the first order conditions are

$$
\begin{gathered}
\frac{\partial L}{\partial K_{0}}=-N\left(-d_{1}\right)+e^{-r T} \operatorname{Cn}\left(d_{2}\right) /\left[\left(K_{0}+D_{0}\right) \sigma \sqrt{T}\right]-\lambda_{1}+\lambda_{2}=0, \\
\frac{\partial L}{\partial \beta}=-\lambda_{2} \frac{\partial K_{\min }(\beta)}{\partial \beta}-\lambda_{3}+\lambda_{4}=\lambda_{2} \varphi_{M} T\left(K_{\min }(\beta)+D_{0}\right)-\lambda_{3}+\lambda_{4}=0,
\end{gathered}
$$

and $\lambda_{i} \geq 0, i=1, \ldots, 4$. The second order conditions are

$$
\begin{gathered}
\frac{\partial^{2} L}{\partial K_{0}^{2}}=\frac{n\left(d_{1}\right)}{\left(K_{0}+D_{0}\right) \sigma \sqrt{T}}-\frac{d_{1} n\left(d_{2}\right) e^{-r T} C}{\left[\left(K_{0}+D_{0}\right) \sigma \sqrt{T}\right]^{2}}, \\
\frac{\partial^{2} L}{\partial \beta^{2}}=-\lambda_{2} \varphi_{M}^{2} T^{2}\left(K_{\min }+D_{0}\right) \leq 0,
\end{gathered}
$$

and $\partial^{2} L / \partial K_{0} \partial \beta=0$. Note from the right-hand side of (A.8) that the first term is $-N\left(-d_{1}\right)<0$ and the second term is $e^{-r T} \operatorname{Cn}\left(d_{2}\right) /\left[\left(K_{0}+D_{0}\right) \sigma \sqrt{T}\right]>0$. Suppose that there exists an interior $K_{0}$ that satisfies (A.8) whereby these two terms are equal in magnitude and, therefore, $\lambda_{1}=\lambda_{2}=0$. Substituting $N\left(-d_{1}\right)$ for $e^{-r T} \operatorname{Cn}\left(d_{2}\right) /\left[\left(K_{0}+D_{0}\right) \sigma \sqrt{T}\right]$ in (A.10) leads to $\partial^{2} L / \partial K_{0}^{2}=\left[n\left(d_{1}\right)-d_{1} N\left(-d_{1}\right)\right] /\left[\left(K_{0}+D_{0}\right) \sigma \sqrt{T}\right]>0$ since $n(x)>x N(-x) .{ }^{56}$ Thus, with a positive second derivative, any interior solution for $K_{0}$ must be a minimum. Consequently, the choice of $K_{0}$ that maximizes excess shareholder value must occur at one of the endpoints, $K_{\min }$ or $K_{\max }$.

Given that any interior solution is a minimum, from (A.8) a necessary condition for $K_{0}=K_{\min }$ to be the global maximum is that $\lambda_{2}=\left.\left(N\left(-d_{1}\right)-e^{-r T} \operatorname{Cn}\left(d_{2}\right) /\left[\left(K_{0}+D_{0}\right) \sigma \sqrt{T}\right]\right)\right|_{K_{0}=K_{\min }(\beta)}>0$ and $\lambda_{1}=0$.

Moreover, with $\lambda_{2}>0$, the first order condition (A.9) implies $\lambda_{3}=\lambda_{2} \varphi_{M} T\left(K_{\min }(\beta)+D_{0}\right)>0$ and $\lambda_{4}=0$, so that $\beta=\beta_{\max }$ binds. Consequently, if the global maximum of excess shareholder value is at the minimum level of capital, then $K_{0}=K_{\min }\left(\beta_{\max }\right)$. In other words, the bank will also choose the highest systematic risk.

\footnotetext{
${ }^{56}$ For example, see formula 26.2.12 on page 932 of Abramowitz and Stegun (1972).
} 
Alternatively, if the global maximum is at $K_{0}=K_{\max }$, then from (A.8) a necessary condition is $\lambda_{1}=\left.\left(e^{-r T} \operatorname{Cn}\left(d_{2}\right) /\left[\left(K_{0}+D_{0}\right) \sigma \sqrt{T}\right]-N\left(-d_{1}\right)\right)\right|_{K_{0}=K_{\max }}>0$ and $\lambda_{2}=0$. With $\lambda_{2}=0$, the first order condition (A.9) implies that bank's choice of $\beta$ is indeterminate. This makes sense since $E_{0}-K_{0}$ is independent of $\beta$ when $K_{0}=K_{\max }$ since the minimum capital constraint in (4) does not bind.

If both $K_{0}=K_{\min }\left(\beta_{\max }\right)$ and $K_{0}=K_{\max }$ satisfy the above necessary conditions for a maximum, which would occur when there is an interior minimum, then determining the global maximum requires using equation (6) to compare $\left.\left(E_{0}-K_{0}\right)\right|_{K_{0}=K_{\min }\left(\beta_{\max }\right)}$ versus $\left.\left(E_{0}-K_{0}\right)\right|_{K_{0}=K_{\max }}$, where the larger is the global maximum. Based on (A.7), (A.8), and our above arguments, note that if $\left(r-r_{d}\right)$ is sufficiently small so that $C$ is sufficiently close to $0, K_{0}=K_{\min }\left(\beta_{\max }\right)$ must be the global maximum. Instead, if $\left(r-r_{d}\right)$ and $C$ are sufficiently large, $K_{0}=K_{\max }$ must be the global maximum.

\section{APPENDIX B - Estimation Details}

Calculation of Issuing Firms' Debt Betas: Following Galai and Masulis (1976) and consistent with the model of individual firms in Appendix A, a firm's debt beta can be derived from its asset beta or equity beta. Let $E_{i, t}$ $=A_{i, t}-D_{i, t}$ be the market value of firm i's shareholders equity, and let $\beta_{A, i}=\sigma_{i} \sigma_{M} \rho_{i, M} / \sigma_{M}^{2}$ be firm i's asset beta. Then firm $i$ 's equity beta $\left(\beta_{E, i}\right)$ and debt beta $\left(\beta_{D, i}\right)$ satisfy:

$$
\begin{gathered}
\beta_{E, i}=\frac{\partial E_{i, t}}{\partial A_{i, t}} \frac{A_{i, t}}{E_{i, t}} \beta_{A, i}=N\left(d_{1, i}\right) \frac{A_{i, t}}{E_{i, t}} \beta_{A, i} \\
\beta_{D, i}=\frac{\partial D_{i, t}}{\partial A_{i, t}} \frac{A_{i, t}}{D_{i, t}} \beta_{A, i}=N\left(-d_{1, i}\right) \frac{A_{i, t}}{D_{i, t}} \beta_{A, i}=\frac{E_{i, t}}{D_{i, t}} \frac{N\left(-d_{1, i}\right)}{N\left(d_{1, i}\right)} \beta_{E, i}
\end{gathered}
$$

where the last equality in equation (B2) is obtained by using equation (B1). Equation (B2) is the same as equation (8) of the text.

Based on equation (B2), a firm's debt beta can be computed from its equity (stock) beta and the market value of the firm's equity, $E_{i, t}$ if we also know the market value of the firm's assets, $A_{i, t}$ and the volatility of the firm's assets, $\sigma_{i}$. Similar to Marcus and Shaked (1984), we solve for $A_{i, t}$ and $\sigma_{i}$ by using information on the market value of the firm's total equity, $E_{i, t}$, and its equity's total volatility, call it $\sigma_{E, i}$ : 


$$
\begin{aligned}
& E_{i, t}=A_{i, t} N\left(d_{1, i}\right)-X_{i} e^{-r \tau_{i}} N\left(d_{2, i}\right) \\
& \sigma_{E, i}=\frac{A_{i, t}}{E_{i, t}} N\left(d_{1, i}\right) \sigma_{i}
\end{aligned}
$$

The two nonlinear equations in (B3) are solved numerically to obtain $A_{i, t}$ and $\sigma_{i}$, where $\tau_{i}=10$ years and $X_{i}$ equals the book value of the firm's debt. For robustness, we also obtain estimates assuming $\tau_{i}=5$ years.

Once $A_{i, t}$ and $\sigma_{i}$ are derived, the firm's debt beta is computed from equation (B2). Based on the same logic of Galai and Masulis (1976), the total volatility and residual volatility of the firm's debt can be computed. The same factor in equation (B2) that converts equity beta to debt beta, $\left[E_{i, t} N\left(-d_{1, i}\right)\right] /\left[D_{i, t} N\left(d_{1, i}\right)\right]$, is used to convert equity total volatility and equity residual volatility to debt total volatility and debt residual volatility. Debt residual volatility is a measure of the idiosyncratic default risk of the firm's bond or loan. Calculation of Banks' Asset Betas and Charter Values:

The variables $E_{0}, A_{0}, D_{T}$, and $C$ in equations (12) to (14) of the text can be normalized by $D_{0}$, which we proxy by the bank holding company's book value of total non-ownership liabilities (debt). For simplicity, we approximate $e^{-r T} D_{T} e^{p T} / D_{0}=1$, which implies $p=\left(r-r_{d}\right)$ and allows us to avoid using data on interest rates. From CRSP and Y9-C Reports or Compustat, we calculate $E_{0} / D_{0}$ and $\sigma_{E}$ for the last trading day of each quarter, where $\sigma_{E}$ is estimated from the prior 52 weekly stock returns.

Since the most common and liquid CDS contract is for senior unsecured debt with a 5-year maturity, we use that contract's spread for $S_{C D S}$ as reported by Markit for the last trading day of each quarter. The variable $L G D^{Q}$ in equation (14) is proxied by 1 minus Markit's reported recovery rate for the same contract. Since the CDS contract is for senior debt, we adjust for any preferred stock and subordinated debt issued by the bank holding company. This is done by computing $d_{2}$ in equation (14) using the ratio of the market value of assets to non-ownership liabilities that excludes preferred stock and subordinated debt.

We assume $T=5$ years when numerically solving the normalized, three-equation system (12) to (14) for the three variables $A_{0} / D_{0}, \sigma$, and $C / D_{0}$. Solutions are obtained for each bank-quarter. Then using the prior 52 weekly bank stock returns and the CRSP value-weighted market index returns, we estimate each bank’s stock beta, $\beta_{E}$, for each end-of-quarter date. The end-of-quarter values of $E_{0} / D_{0}, A_{0} / D_{0}, C / D_{0}, \sigma$, and $\beta_{E}$ allow us to calculate end-of-quarter values of the bank's asset return beta, $\beta_{A}$, using equation (15) in the text. 


\section{APPENDIX C - Variable Description}

Spread

The bond's or loan's credit spread. For a bond it equals the bond's yield at issuance minus the contemporaneous yield on a Treasury security of the same maturity and currency. For floating-rate loans, it is the all-in-drawn spread over LIBOR as reported in DealScan.

Rating Indicator variables for bond or loan ratings (at the notch level).

Avg_Rating* The average of Moody's and S\&P's rating (at the notch level) converted into a numerical scale $(\mathrm{AAA} / \mathrm{Aaa}=1, \mathrm{AA}+/ \mathrm{Aa} 1=2, \ldots, \mathrm{BBB}-/ \mathrm{Bbb} 3=10)$.

Debt Beta

The issuer's or borrower's debt beta, derived from the issuer's Equity Beta as detailed in Appendix B. For bond issuers, Equity Beta is computed from weekly returns of the issuer's stock and the MSCI World Index using a standard market model estimated during the 52 weeks preceding each issue. For syndicated loan borrowers, Equity Beta is computed from weekly returns of the borrowing firm's stock and the CRSP Valueweighted Index using a standard market model estimated during the 52 weeks preceding each issue. From this model we also get the Equity Residual Volatility.

Debt Res. Vol. The issuer's debt residual volatility, estimated from the Equity Residual Volatility as detailed in Appendix B.

Bank Weighted A weighted average of the debt betas of the borrowers to whom the bank granted

Debt Beta** credit via the syndicated loan market in a given year, using the relative size of the bank's investment in each loan as weights.

Bank Weighted A weighted average of the credit rating-adjusted spreads of the syndicated loans

Excess Spread** originated by the bank in a given year, using the relative size of the bank's investment in each loan as weights.

Bank Asset Beta The beta of a bank holding company's total assets, estimated from market values of equity, CDS spreads, and balance sheet data as detailed in Appendix B.

\section{Controls}

Bond or Loan characteristics

\begin{tabular}{|l|l|}
\hline Face Value & The natural log of the USD equivalent face value of bond or loan. \\
\hline Maturity & The natural log of the years to maturity of the bond or loan. \\
\hline Seniority & A dummy variable equal to 1 if the bond or loan is subordinated. \\
\hline International Mkt* & A dummy variable equal to 1 if the bond is a eurobond. \\
\hline Negative Pledge* & $\begin{array}{l}\text { A dummy variable that equals } 1 \text { if the bond issue has a negative pledge clause. The } \\
\text { negative pledge clause restricts the issuer from using its assets as collateral for } \\
\text { future debt obligations. }\end{array}$ \\
\hline Reg $D^{*}$ & A dummy variable equal to 1 if the bond is Regulation D. \\
\hline Reg $S^{*}$ & A dummy variable equal to 1 if the bond is Regulation S. \\
\hline
\end{tabular}




\begin{tabular}{|l|l|}
\hline Rule 144a* & A dummy variable equal to 1 if the bond is Rule 144a. \\
\hline Fungible* & A dummy variable equal to 1 if the bond is fungible. \\
\hline Force majeure* & A dummy variable equal to 1 if the bond has a force majeure clause. \\
\hline Shelf registration* & A dummy variable equal to 1 if the bond is shelf-registered. \\
\hline Cross-default* & $\begin{array}{l}\text { A dummy variable that equals } 1 \text { if the bond issue has a cross-default clause. The } \\
\text { cross-default clause avoids the possibility of selective default on the part of the } \\
\text { issuer. If the issuer is insolvent on one loan or bond issue, it is automatically } \\
\text { considered as insolvent on all other loans and obligations. }\end{array}$ \\
\hline Year & Year fixed effects. \\
\hline Currency* & Currency fixed effects. \\
\hline Bid-Ask Spread* & $\begin{array}{l}\text { The average bid-ask spread over the } 60 \text { trading days following the issuance of each } \\
\text { bond. This variable is available for } 2,395 \text { bonds (out of the entire sample of 3,924 } \\
\text { bonds). }\end{array}$ \\
\hline Credit Line
\end{tabular}

Bond issuer or firm borrower characteristics

\begin{tabular}{|l|l|}
\hline Size & The natural log of the USD equivalent issuer's market capitalization. \\
\hline Country* & Country fixed effects. \\
\hline Industry & Industry fixed effects. \\
\hline
\end{tabular}

Bank characteristics

\begin{tabular}{|l|l|}
\hline Ln (Assets) & The natural log of the bank holding company’s total assets. \\
\hline Capital-Asset Ratio & The bank holding company’s Tier 1 capital to total assets ratio. \\
\hline Capital-RWA Ratio & The bank holding company's Tier 1 capital to risk-weighted assets ratio. \\
\hline Equity-Asset Ratio & The bank holding company's book-value of common equity-to-assets ratio. \\
\hline Charter Value & $\begin{array}{l}\text { The bank holding company's charter value-to-debt ratio estimated from market } \\
\text { values of equity, CDS spreads, and balance sheet data as detailed in Appendix B. }\end{array}$ \\
\hline
\end{tabular}

*Used for bonds only

**Used for syndicated loans only 
Figure 1 - Bond Issuers’ Average Debt Beta by Year

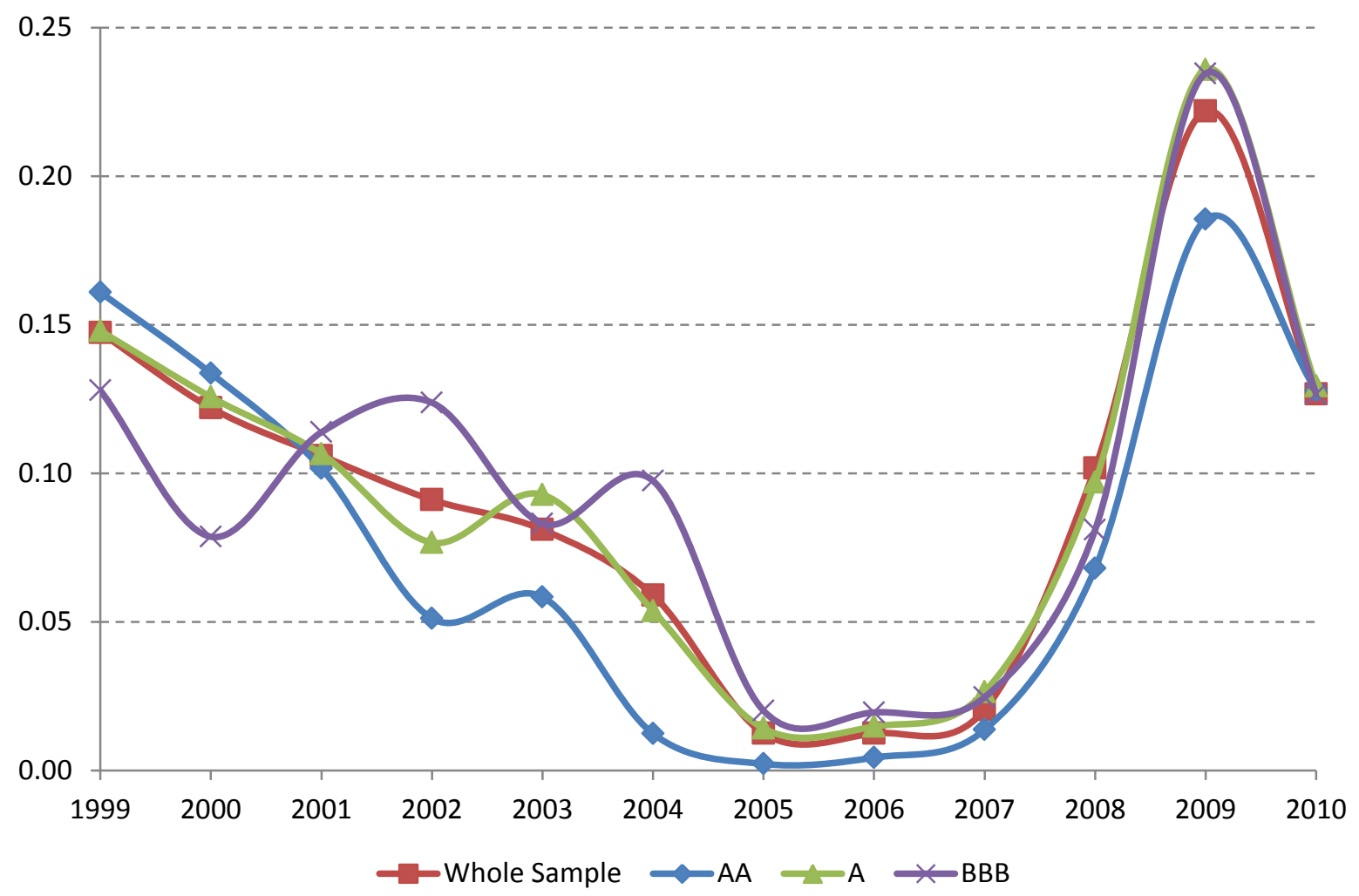

Figure 2 - Syndicated Loan Borrowers’ Average Debt Beta by Year

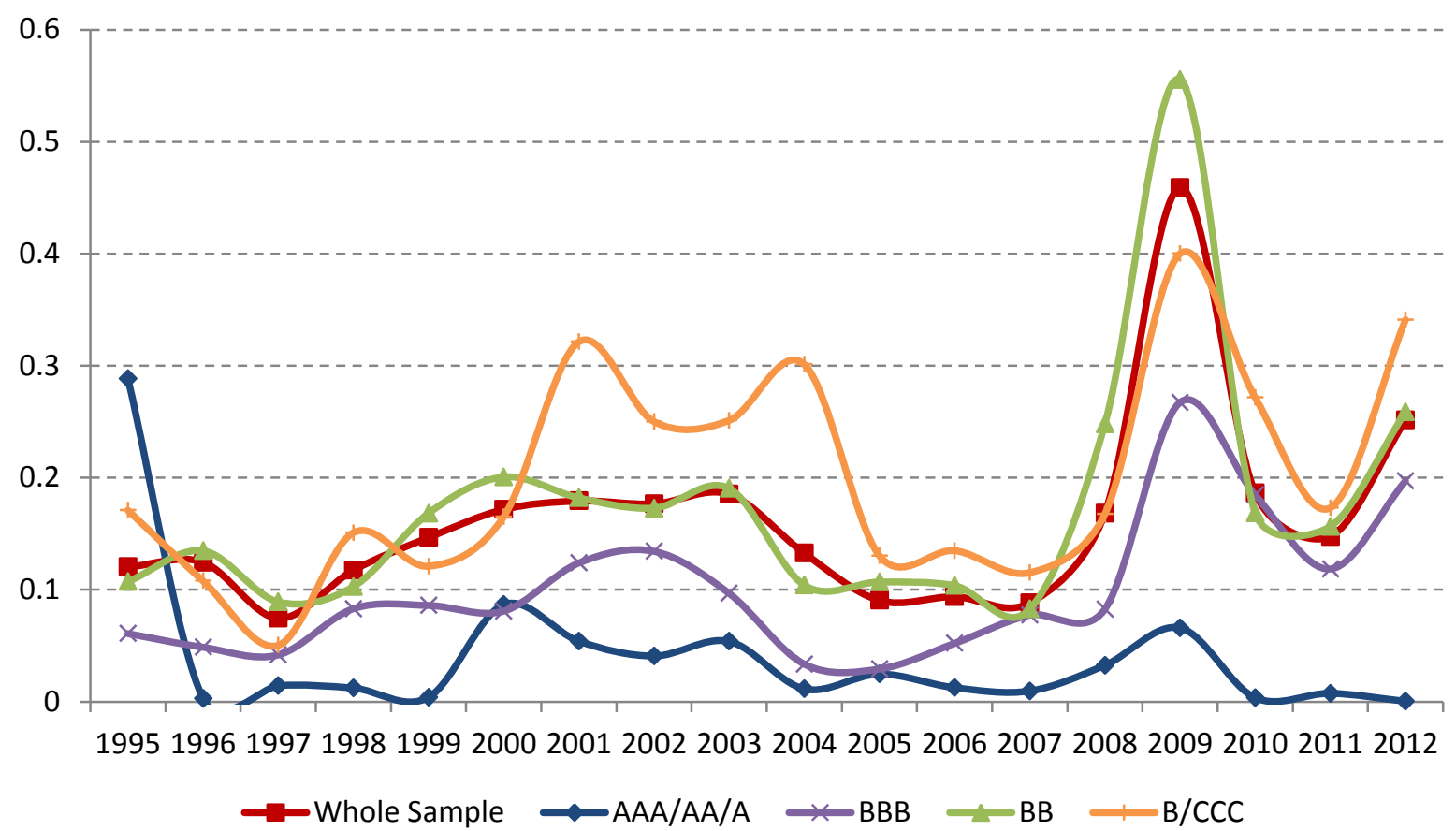


Table 1 - Bond Summary Statistics

Detailed variable descriptions are reported in Appendix C.

\begin{tabular}{cccccccc}
\hline \multicolumn{8}{c}{ Panel A: Variable Mean by Credit Rating } \\
\hline \multirow{2}{*}{ Rating } & \multirow{2}{*}{ Obs. } & \multirow{2}{*}{ Spread } & Maturity & Face Value & \multicolumn{2}{c}{ Debt } \\
\cline { 6 - 8 } & & & (years) & (USD, m) & Beta & Res. Vol \\
\hline AAA/Aaa & 132 & 80.70 & 4.82 & 1,820 & 0.20 & 1.03 \\
AA/Aa & 1,156 & 88.20 & 7.81 & 889 & 0.08 & 0.34 \\
A/A & 1,587 & 114.82 & 8.44 & 864 & 0.10 & 0.44 \\
BBB/Baa & 1,049 & 149.05 & 8.01 & 661 & 0.10 & 0.54 \\
\hline Total & 3,924 & 114.98 & 8.02 & 849 & 0.10 & 0.46 \\
\hline
\end{tabular}

\begin{tabular}{cccccccc}
\hline \multicolumn{7}{c}{ Panel B: Variable Mean by Year } \\
\hline \multirow{2}{*}{ Year } & Obs. & Spread & Rating & Maturity & Face Value & \multicolumn{2}{c}{ Debt } \\
\cline { 7 - 9 } & & & & (years) & (USD, m) & Beta & Res. Vol \\
\hline 1999 & 158 & 104.40 & 5.54 & 9.10 & 836 & 0.15 & 0.52 \\
2000 & 219 & 112.08 & 5.42 & 7.40 & 974 & 0.12 & 0.61 \\
2001 & 337 & 114.04 & 6.22 & 8.02 & 1,030 & 0.11 & 0.54 \\
2002 & 305 & 93.99 & 6.60 & 9.23 & 776 & 0.09 & 0.46 \\
2003 & 376 & 72.11 & 6.71 & 8.77 & 606 & 0.08 & 0.42 \\
2004 & 275 & 49.58 & 6.32 & 7.74 & 547 & 0.06 & 0.21 \\
2005 & 284 & 45.70 & 5.99 & 7.81 & 521 & 0.01 & 0.05 \\
2006 & 292 & 60.41 & 5.78 & 9.05 & 735 & 0.01 & 0.06 \\
2007 & 353 & 77.98 & 5.19 & 8.99 & 796 & 0.02 & 0.06 \\
2008 & 393 & 173.70 & 4.83 & 7.67 & 997 & 0.10 & 0.45 \\
2009 & 554 & 215.63 & 5.27 & 6.65 & 1,120 & 0.22 & 1.13 \\
2010 & 378 & 149.29 & 5.53 & 7.21 & 988 & 0.13 & 0.46 \\
\hline Total & 3,924 & 114.98 & 5.75 & 8.02 & 849 & 0.10 & 0.46 \\
\hline
\end{tabular}


Table 2 - Regression of Bond Credit Spreads on Ratings and Debt Systematic Risk

Columns (1) and (3) report coefficients of OLS regressions with robust standard errors clustered both at the year and issuer level. Columns (2) and (4) report average coefficients from yearly Fama-MacBeth regressions that control for ratings-by-time fixed effects. The dependent variable is Spread, equal to the difference between the bond yield at issuance and the Treasury yield of the same maturity and currency. Detailed variable descriptions are reported in Appendix C. Coefficients for control variables are not reported for ease of exposition. t-statistics are given in parentheses. $* * *, * *, *$ indicate significance at $1 \%, 5 \%, 10 \%$ level, respectively.

\begin{tabular}{ccccc}
\hline & $\mathbf{( 1 )}$ & $\mathbf{( 2 )}$ & $\mathbf{( 3 )}$ & $\mathbf{( 4 )}$ \\
\hline & \multicolumn{3}{c}{ Whole Sample } & \multicolumn{1}{c}{ Bid-Ask Spread Sample } \\
\hline & $82.16^{* * *}$ & 18.74 & $100.42^{* *}$ & Fama-MacBeth \\
\hline \multirow{2}{*}{ AA+/Aa1 } & $(4.02)$ & $(1.12)$ & $(2.53)$ & $(-0.42)$ \\
& $92.15^{* * *}$ & 21.00 & $114.86^{* * *}$ & -2.98 \\
& $(3.95)$ & $(1.03)$ & $(2.91)$ & $(-0.10)$ \\
\hline \multirow{2}{*}{ AA/Aa2 } & $111.65^{* * *}$ & 32.77 & $130.24^{* * *}$ & 9.84 \\
& $(4.38)$ & $(1.62)$ & $(3.04)$ & $(0.30)$ \\
\hline \multirow{2}{*}{ AA-/Aa3 } & $119.28^{* * *}$ & $42.59^{* *}$ & $129.44^{* * *}$ & 15.09 \\
& $(4.03)$ & $(1.96)$ & $(3.09)$ & $(0.48)$ \\
\hline \multirow{2}{*}{ A+/A1 } & $134.28^{* * *}$ & $54.17^{* *}$ & $145.40^{* * *}$ & 32.34 \\
& $(4.33)$ & $(2.28)$ & $(3.24)$ & $(0.94)$ \\
\hline \multirow{2}{*}{ A/A2 } & $153.90^{* * *}$ & $61.81^{* * *}$ & $155.41^{* * *}$ & 36.23 \\
& $(4.89)$ & $(2.81)$ & $(3.97)$ & $(1.20)$ \\
\hline \multirow{2}{*}{ A-/A3 } & $182.43^{* * *}$ & $87.52^{* * *}$ & $176.56^{* * *}$ & $55.10^{*}$ \\
& $(4.55)$ & $(3.14)$ & $(4.11)$ & $(1.81)$ \\
\hline \multirow{2}{*}{ BBB+/Baa1 } & $196.32^{* * *}$ & $99.77^{* * *}$ & $193.21^{* * *}$ & $79.07^{* *}$ \\
& $(4.15)$ & $(3.04)$ & $(3.72)$ & $(2.11)$ \\
\hline \multirow{2}{*}{ BBB/Baa2 } & $208.11^{* * *}$ & $107.14^{* * *}$ & $209.93^{* * *}$ & $95.57^{* * *}$ \\
& $(4.75)$ & $(4.06)$ & $(4.56)$ & $(2.98)$ \\
\hline \multirow{2}{*}{ BBB-/Baa3 } & $105.42^{* * *}$ & $82.91^{* * *}$ & $139.49^{* * *}$ & $91.67^{* *}$ \\
& $(3.44)$ & $(4.75)$ & $(3.69)$ & $(2.33)$ \\
\hline \multirow{2}{*}{ Bid-Ask Spread } & 0.432 & 1.57 & -1.185 & 1.75 \\
& $(0.21)$ & $(0.88)$ & $(-0.65)$ & $(1.07)$ \\
\hline \multirow{2}{*}{ Debt Beta } & & & $90.44^{* * *}$ & $86.97^{* *}$ \\
& 3,924 & 3,924 & 2,395 & 2,395 \\
\hline \multirow{2}{*}{ Adj. R ${ }^{2}$} & 0.62 & 0.74 & 0.66 & 0.75 \\
\hline & & &
\end{tabular}


Table 3 - Syndicated Loan Summary Statistics

Detailed variable descriptions are reported in Appendix C.

\begin{tabular}{crrccccc}
\hline \multicolumn{8}{c}{ Panel A: Variable Mean by Credit Rating } \\
\hline \multirow{2}{*}{ Rating } & \multirow{2}{*}{ Obs. } & Spread & $\begin{array}{c}\text { Maturity } \\
\text { (years) }\end{array}$ & $\begin{array}{c}\text { Face Value } \\
\text { (USD, m) }\end{array}$ & \multicolumn{2}{c}{ Beta } & Res. Vol \\
\hline AAA/AA/A & 170 & 42.08 & 3.67 & 1,499 & 0.03 & 0.01 \\
BBB & 516 & 120.31 & 4.36 & 765 & 0.08 & 0.02 \\
BB & 1,683 & 236.19 & 5.38 & 427 & 0.15 & 0.07 \\
B/CCC & 746 & 311.56 & 5.53 & 383 & 0.18 & 0.11 \\
\hline Total & 3,115 & 224.45 & 5.15 & 531 & 0.14 & 0.07 \\
\hline
\end{tabular}

\begin{tabular}{cccccccc}
\hline \multicolumn{7}{c}{ Panel B: Variable Mean by Year } \\
\hline \multirow{2}{*}{ Year } & Obs. & Spread & Rating & $\begin{array}{c}\text { Maturity } \\
\text { (years) }\end{array}$ & $\begin{array}{c}\text { Face Value } \\
\text { (USD, m) }\end{array}$ & Beta & Res. Vol \\
\hline 1995 & 90 & 174.60 & 12.36 & 5.14 & 234 & 0.12 & 0.07 \\
1996 & 78 & 199.81 & 12.40 & 5.01 & 242 & 0.12 & 0.12 \\
1997 & 51 & 190.73 & 12.41 & 5.79 & 351 & 0.07 & 0.08 \\
1998 & 74 & 213.41 & 12.54 & 6.05 & 291 & 0.11 & 0.07 \\
1999 & 92 & 244.59 & 12.25 & 6.19 & 394 & 0.15 & 0.10 \\
2000 & 150 & 253.17 & 12.38 & 5.74 & 323 & 0.17 & 0.16 \\
2001 & 142 & 217.02 & 11.61 & 4.76 & 377 & 0.18 & 0.15 \\
2002 & 189 & 266.17 & 12.13 & 4.76 & 333 & 0.18 & 0.12 \\
2003 & 218 & 255.79 & 11.93 & 4.41 & 345 & 0.19 & 0.11 \\
2004 & 332 & 197.58 & 11.85 & 4.91 & 453 & 0.13 & 0.05 \\
2005 & 399 & 173.75 & 11.72 & 5.12 & 538 & 0.09 & 0.03 \\
2006 & 325 & 170.64 & 11.65 & 5.30 & 719 & 0.09 & 0.03 \\
2007 & 402 & 194.19 & 12.10 & 5.47 & 864 & 0.09 & 0.03 \\
2008 & 85 & 265.24 & 11.62 & 4.73 & 998 & 0.17 & 0.06 \\
2009 & 51 & 360.20 & 11.61 & 3.89 & 364 & 0.46 & 0.22 \\
2010 & 154 & 338.56 & 11.95 & 4.96 & 456 & 0.19 & 0.08 \\
2011 & 215 & 291.27 & 11.64 & 5.43 & 615 & 0.15 & 0.04 \\
2012 & 68 & 306.68 & 11.69 & 5.28 & 692 & 0.25 & 0.08 \\
\hline Total & 3,115 & 224.45 & 11.93 & 5.15 & 531 & 0.14 & 0.07 \\
\hline & & & & & & &
\end{tabular}




\section{Table 4 - Regression of Syndicated Loan Spreads on Ratings and Debt Systematic Risk}

Columns (1) and (2) report coefficients of OLS regressions with robust standard errors clustered both at the year and issuer level. Columns (3) and (4) report average coefficients from yearly Fama-MacBeth regressions that control for ratings-by-time fixed effects. The dependent variable is the syndicated loan all-in Spread. Detailed variable descriptions are reported in Appendix C. Coefficients for control variables are not reported for ease of exposition. t-statisics are given in parentheses. ${ }^{* * *}, * *, *$ indicate significance at $1 \%$, $5 \%, 10 \%$ level, respectively.

\begin{tabular}{ccccc}
\hline & $\mathbf{( 1 )}$ & $\mathbf{( 2 )}$ & $\mathbf{( 3 )}$ & $\mathbf{( 4 )}$ \\
\hline & & \multicolumn{3}{c}{ Fama-MacBeth } \\
\hline \multirow{2}{*}{ BBB } & $47.47^{* * *}$ & $41.70^{* * *}$ & $49.32^{* * *}$ & $26.06^{*}$ \\
& $(8.71)$ & $(7.10)$ & $(6.39)$ & $(1.92)$ \\
\hline \multirow{2}{*}{ BB } & $111.45^{* * *}$ & $102.67^{* * *}$ & $111.80^{* * *}$ & $83.52^{* * *}$ \\
& $(16.14)$ & $(13.55)$ & $(13.79)$ & $(5.43)$ \\
\hline \multirow{2}{*}{ B } & $176.36^{* * *}$ & $165.71^{* * *}$ & $168.19^{* * *}$ & $132.15^{* * *}$ \\
& $(21.33)$ & $(17.92)$ & $(11.50)$ & $(8.25)$ \\
\hline \multirow{2}{*}{ CCC } & $276.64^{* * *}$ & $265.36^{* * *}$ & $163.05^{* * *}$ & $146.74^{* * *}$ \\
& $(8.27)$ & $(7.84)$ & $(4.40)$ & $(4.39)$ \\
\hline \multirow{2}{*}{ Debt Beta } & $109.24^{* * *}$ & $83.30^{* * *}$ & $99.63^{* * *}$ & $41.71^{* *}$ \\
& $(7.37)$ & $(4.47)$ & $(7.88)$ & $(2.36)$ \\
\hline \multirow{2}{*}{$\ln$ (Debt Residual Volatility) } & & $4.74^{* * *}$ & & $12.06^{* * *}$ \\
& & $(3.31)$ & & $(3.89)$ \\
\hline Obs. & 3,115 & 3,115 & 3,115 & 3,115 \\
\hline Adj. R & 0.65 & 0.65 & 0.66 & 0.68 \\
\hline
\end{tabular}


Table 5 - Regressions of Credit Ratings on Debt Systematic Risk

Columns 1 and 2 reports coefficients of OLS regressions with robust standard errors clustered both at the year and issuer level while Columns 3 and 4 reports average coefficients of yearly Fama-MacBeth regressions. Column 5 reports the results of an ordered probit model. Panel A uses corporate bond data where the dependent variable is a bond's Avg_Rating, i.e. the average of Moody's and S\&P's issue ratings, converted into numerical scale $(\mathrm{AAA} / \mathrm{Aaa}=1, \mathrm{AA}-/ \mathrm{Aa} 1=2, \ldots, \mathrm{BBB}-/ \mathrm{Bbb} 3=10)$. Panel B uses syndicated loan data where the dependent variable is a syndicated loan's Moody's rating, except when unavailable it is replaced with the loan's $S \& P$ rating. Ratings are also converted to the same numerical scale (AAA/Aaa $=1$, $\mathrm{AA}-/ \mathrm{Aa} 1=2, \ldots, \mathrm{BBB}-/ \mathrm{Bbb3}=10)$. Coefficients for control variables are not reported for ease of exposition. Detailed variable descriptions are reported in Appendix C. $t$-statistics are given in parentheses. $* * *, * *, *$ indicate significance at $1 \%, 5 \%, 10 \%$ level, respectively.

\section{A. Corporate Bond Credit Ratings}

\begin{tabular}{|c|c|c|c|c|c|}
\hline & (1) & (2) & (3) & (4) & (5) \\
\hline & & & \multicolumn{2}{|c|}{ Fama-MacBeth } & Probit \\
\hline Debt Beta & $\begin{array}{c}1.875^{* * * *} \\
(2.73)\end{array}$ & $\begin{array}{l}0.917 \\
(1.28) \\
\end{array}$ & $\begin{array}{c}4.25 * * * \\
(3.39)\end{array}$ & $\begin{array}{l}1.827^{*} \\
(1.809) \\
\end{array}$ & $\begin{array}{c}0.639 * * * \\
(3.48)\end{array}$ \\
\hline In (Debt Residual Volatility) & & $\begin{array}{c}0.123^{* * *} \\
(4.12)\end{array}$ & & $\begin{array}{c}0.147 * * * \\
(3.50)\end{array}$ & $\begin{array}{c}0.076 * * * \\
(6.48)\end{array}$ \\
\hline Obs. & 3,924 & 3,924 & 3,924 & 3,924 & 3,924 \\
\hline Adj. $\mathrm{R}^{2}$ & 0.47 & 0.48 & 0.67 & 0.69 & \\
\hline
\end{tabular}

B. Syndicated Loan Credit Ratings

\begin{tabular}{|c|c|c|c|c|c|}
\hline & (1) & (2) & (3) & (4) & (5) \\
\hline & & & \multicolumn{2}{|c|}{ Fama-MacBeth } & Probit \\
\hline Debt Beta & $\begin{array}{c}2.69 * * * \\
(9.04)\end{array}$ & $\begin{array}{c}-0.25 \\
(-0.63)\end{array}$ & $\begin{array}{c}2.75^{* * *} \\
(7.82)\end{array}$ & $\begin{array}{c}-0.69 \\
(-1.17)\end{array}$ & $\begin{array}{c}0.06 \\
(0.26)\end{array}$ \\
\hline ln (Debt Residual Volatility) & & $\begin{array}{c}0.49 * * * \\
(8.88)\end{array}$ & & $\begin{array}{c}0.75^{* * *} \\
(3.34)\end{array}$ & $\begin{array}{c}0.27 * * * \\
(8.48)\end{array}$ \\
\hline Obs. & 3,115 & 3,115 & 3,115 & 3,115 & 3,115 \\
\hline Adj. $R^{2}$ & 0.42 & 0.49 & 0.59 & 0.30 & \\
\hline
\end{tabular}




\section{Table 6 - Regressions of Bank Loan Systematic Risk and Capital}

Reported are coefficients of OLS regressions with robust standard errors clustered both at the year and bank level. The sample period is 1995 to 2010. The dependent variable is a bank's choice of newly-originated syndicated loan Systematic Risk for a given year. It is measured in one of two ways: Debt Beta is a weighted average of the debt betas of the firms to whom the bank granted credit via the syndicated loan market, using the relative size of the bank's investment in each loan as weights. Excess Spread is a weighted average of the credit rating-adjusted spreads of the syndicated loans originated by the bank, using the relative size of the bank's investment in each loan as weights. Capital-Asset Ratio and Capital-RWA Ratio are the bank's prior-year Tier 1 capital to total assets ratio and Tier 1 capital to risk-weighted assets ratio, respectively. Ln (Assets) is the natural log of the bank's prior-year total assets. Detailed variable description is reported in Appendix C. Regressions include a set of yearly fixed effects. t-statistics are in parentheses. ***, **, * indicate significance at $1 \%, 5 \%, 10 \%$ level, respectively.

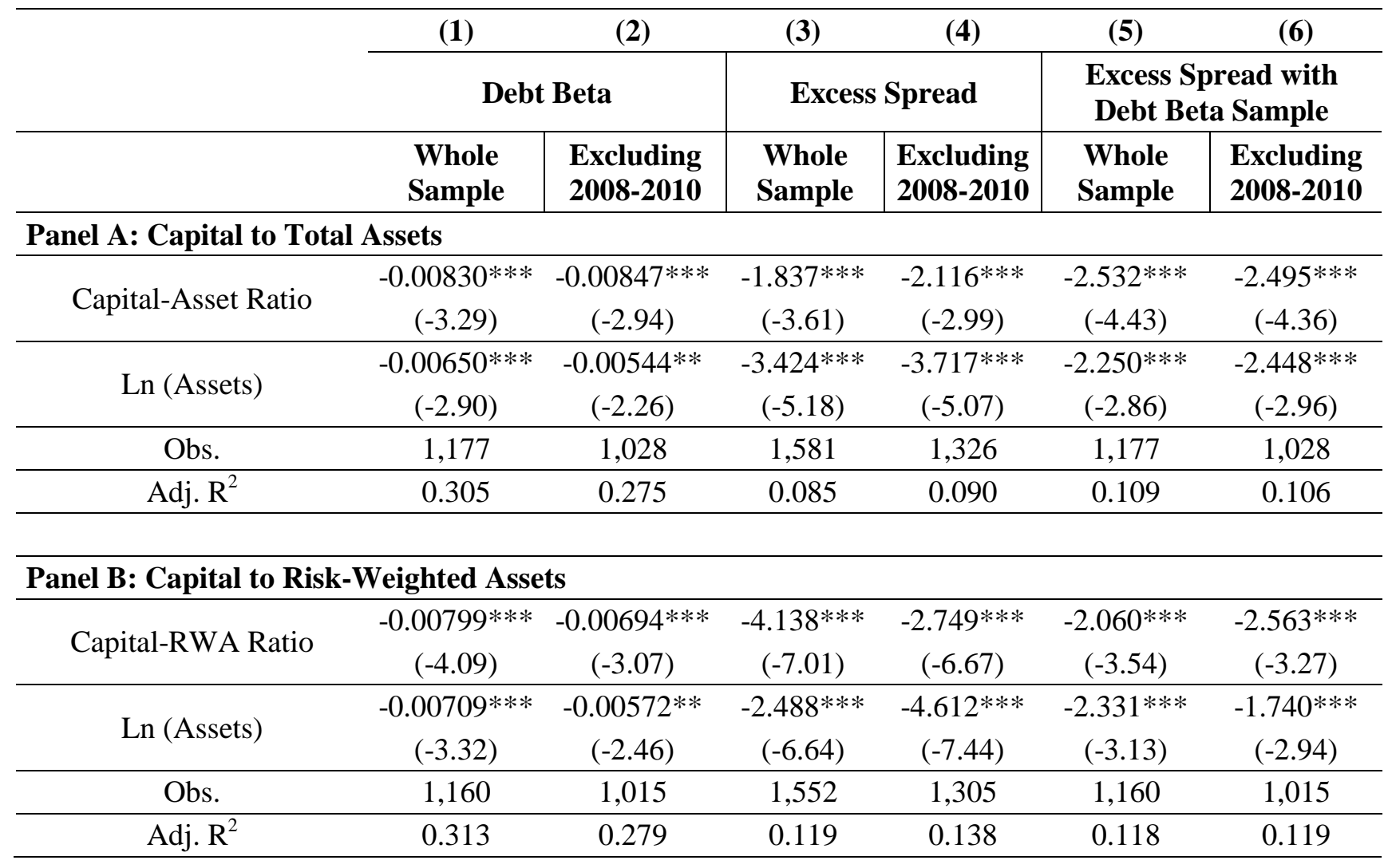


Table 7 - Bank Summary Statistics

Detailed variable descriptions are reported in Appendix C.

Panel A: All Bank Holding Companies

\begin{tabular}{cccccc}
\hline & Mean & Standard Dev. & Minimum & Median & Maximum \\
\hline Bank Asset Beta, $\beta_{A}$ & 0.1747 & 0.1045 & 0.0571 & 0.1446 & 0.4604 \\
Charter Value, $C / D_{0}$ & 0.0407 & 0.0517 & 0.0000 & 0.0177 & 0.1730 \\
Total Assets (\$Billions) & 506 & 595 & 9 & 217 & 2,520 \\
Equity Ratio & 0.0794 & 0.0228 & 0.0468 & 0.0751 & 0.1345 \\
\hline \multicolumn{7}{c}{ Panel B: Traditional Banks Only } \\
\hline \multicolumn{7}{c}{ Mean } & Standard Dev. & Minimum & Median & Maximum \\
\hline \multicolumn{7}{c}{0.0777} & 0.0571 & 0.1423 & 0.4604 \\
Bank Asset Beta, $\beta_{A}$ & 0.1578 & 0.0476 & 0.0000 & 0.0263 & 0.1730 \\
Charter Value, $C / D_{0}$ & 0.0407 & 678 & 9 & 203 & 2,520 \\
Total Assets (\$Billions) & 537 & 0.0182 & 0.0517 & 0.0747 & 0.1219 \\
Capital Ratio & 0.0774 & \multicolumn{7}{c}{}
\end{tabular}

Table 8 - Regressions of Bank Systematic Risk and Charter Value

Reported are coefficients of OLS regressions with robust standard errors. As indicated in the table, the regressions adjust for different types of fixed effects and employ different data subsamples. The sample period is 2001Q4 to 2014Q4. The dependent variable is a bank holding company's asset Systematic Risk, equal to Bank Asset Beta. Bank Asset Beta is a model-implied estimate of the beta of the bank holding company's total asset returns. Charter Value is the bank holding company's modelimplied charter value-to-debt ratio. Ln (Assets) is the natural log of the holding company's prior quarter total assets. Capital-Asset Ratio is the bank holding company's prior-quarter Tier 1 capitalto-assets ratio. Equity-Asset Ratio is the bank holding company's book value of common equity-toassets ratio. Detailed variable descriptions are reported in Appendix C. $t$-statistics are in parentheses. $* * *, * *, *$ indicate significance at $1 \%, 5 \%, 10 \%$ level, respectively.

(1)

(2)

All Years, 2001 to 2014

\begin{tabular}{|c|c|c|c|c|c|c|}
\hline & (1) & (2) & (3) & (4) & (5) & (6) \\
\hline Charter Value & $\begin{array}{c}-0.285^{* *} \\
(-2.25)\end{array}$ & $\begin{array}{c}-0.521 * * * \\
(-5.32)\end{array}$ & $\begin{array}{c}-0.470 * * * \\
(-2.92)\end{array}$ & $\begin{array}{c}-0.440 \text { *** } \\
(-4.01)\end{array}$ & $\begin{array}{l}-0.394^{*} \\
(-1.84)\end{array}$ & $\begin{array}{c}-0.394 * * * \\
(-3.08)\end{array}$ \\
\hline Ln (Assets) & $\begin{array}{l}-0.012 \\
(0.001)\end{array}$ & $\begin{array}{c}-0.046 * * * \\
(-3.357)\end{array}$ & $\begin{array}{l}-0.017 \\
(-1.00)\end{array}$ & $\begin{array}{c}-0.051^{* *} \\
(-2.51)\end{array}$ & $\begin{array}{l}-0.007 \\
(-0.38)\end{array}$ & $\begin{array}{c}-0.048 * * \\
(-2.04)\end{array}$ \\
\hline Capital-Asset Ratio & $\begin{array}{c}0.391 \\
(-0.54)\end{array}$ & $\begin{array}{c}0.173 \\
(-0.61)\end{array}$ & $\begin{array}{c}1.075^{* * *} \\
(-2.99)\end{array}$ & & $\begin{array}{c}1.302 * * * \\
(-3.134)\end{array}$ & \\
\hline Equity-Asset Ratio & & & & $\begin{array}{c}1.347^{* * *} \\
(-4.28)\end{array}$ & & $\begin{array}{c}1.376^{* * *} \\
(-3.61)\end{array}$ \\
\hline Traditional Banks Only & Yes & Yes & Yes & No & Yes & No \\
\hline Bank Fixed Effects & No & Yes & Yes & Yes & Yes & Yes \\
\hline Time Fixed Effects & No & No & Yes & Yes & Yes & Yes \\
\hline Observations & 669 & 669 & 669 & 1,059 & 550 & 872 \\
\hline Adjusted $\mathrm{R}^{2}$ & 0.081 & 0.563 & 0.709 & 0.768 & 0.723 & 0.772 \\
\hline
\end{tabular}

(5) (6)

(4)

Excluding 2008 - 2009 